IZA DP No. 5827

Employed and Unemployed Job Seekers: Are They Substitutes?

Simonetta Longhi

Mark Taylor

June 2011 


\title{
Employed and Unemployed Job Seekers: Are They Substitutes?
}

\author{
Simonetta Longhi \\ ISER, University of Essex \\ and IZA \\ Mark Taylor \\ ISER, University of Essex
}

\section{Discussion Paper No. 5827 \\ June 2011}

IZA

P.O. Box 7240

53072 Bonn

Germany

Phone: +49-228-3894-0

Fax: +49-228-3894-180

E-mail: iza@iza.org

\begin{abstract}
Any opinions expressed here are those of the author(s) and not those of IZA. Research published in this series may include views on policy, but the institute itself takes no institutional policy positions.

The Institute for the Study of Labor (IZA) in Bonn is a local and virtual international research center and a place of communication between science, politics and business. IZA is an independent nonprofit organization supported by Deutsche Post Foundation. The center is associated with the University of Bonn and offers a stimulating research environment through its international network, workshops and conferences, data service, project support, research visits and doctoral program. IZA engages in (i) original and internationally competitive research in all fields of labor economics, (ii) development of policy concepts, and (iii) dissemination of research results and concepts to the interested public.
\end{abstract}

IZA Discussion Papers often represent preliminary work and are circulated to encourage discussion. Citation of such a paper should account for its provisional character. A revised version may be available directly from the author. 
IZA Discussion Paper No. 5827

June 2011

\section{ABSTRACT}

\section{Employed and Unemployed Job Seekers: Are They Substitutes?*}

The job search literature suggests that on-the-job search reduces the probability of unemployed people finding a job. However, there is no evidence that employed and unemployed job seekers are similar or apply for the same jobs. We combine the Labour Force Survey and the British Household Panel Survey to compare employed and unemployed job seekers in terms of individual characteristics, preferences over working hours, job-search strategies, and employment histories. We find substantial differences, which persist over the business cycle and remain after controlling for unobserved heterogeneity. We conclude that the unemployed do not directly compete with employed job seekers.

JEL Classification: J29, J60

Keywords: on-the-job search, unemployment, job competition, employment histories, panel data

Corresponding author:

Simonetta Longhi

Institute for Social and Economic Research

University of Essex

Colchester Essex C04 3SQ

United Kingdom

E-mail: slonghi@essex.ac.uk

\footnotetext{
* This paper forms part of the project "Job search in the UK 1990-2006", funded by the Leverhulme Trust Grant no. F/O0 213/O; it also forms part of a programme of research funded by the Economic and Social Research Council through their grant to the Research Centre on Micro-social Change in ISER. The support provided by the ESRC and the University of Essex is gratefully acknowledged. LFS and BHPS data are available from the Data Archive at the University of Essex (www.data-archive.ac.uk).
} 


\section{INTRODUCTION}

Workers move from job to job and into and out of employment as they attempt to maximise their wages and find a suitable employer. According to job search theory, employed workers seek better paying jobs while the unemployed seek jobs that offer wages exceeding their reservation wage (Burdett and Mortensen 1998). Most models assume that job seekers are homogeneous, with employed and unemployed job seekers differing only in their labour market status and search intensity and effectiveness. However there is little empirical evidence that employed and unemployed job seekers have similar observed characteristics, which prompts the question of whether the employed and unemployed compete for the same jobs. Our contribution to the literature is to compare the characteristics and behaviour of employed and unemployed job seekers. If they are observationally different, then in contrast to the assumptions made in the theoretical literature we cannot conclude that they directly compete with each other for the same job vacancies, or that the experience and decisions of one group will influence the outcomes of the other.

In models such as Burdett and Mortensen (1998) and van den Berg and Ridder (1998), both employed and unemployed job seekers apply for the same jobs. As potential employers cannot observe the productivity of job applicants, they may interpret previous or current unemployment as a signal of low productivity. Hence, when receiving applications from employed and unemployed job seekers, employers prefer job applicants who are employed (Eriksson and Gottfries 2005). Consequently the presence of employed job seekers should reduce the chances of unemployed people finding work (Rogerson et al. 2005).

The empirical literature supports the theoretical predictions that employers prefer hiring applicants who are already in work (Eckstein and van den Berg 2007). Some authors reach this conclusion by estimating matching functions using aggregate data on hirings and flows out of unemployment (e.g. Anderson and Burgess 2000), with a higher proportion of employed job seekers reducing the probability of unemployed people finding a job (Burgess 1993). Furthermore, Robson (2001) suggests that regional differences in outflows from unemployment are related to differences in the competitiveness of unemployed compared to employed job seekers. In this sense, employed and unemployed job seekers are seen as substitutes.

Studies using micro-data also find that employed job seekers receive more job offers than the unemployed (Blau and Robins 1990), although this is partly explained by differences in individual characteristics (Eriksson and Lagerstrom 2006). Andrews et al. (2001) conclude that employers rank job seekers by their labour market state, although the extent to which 
employed and unemployed job seekers apply for the same vacancies is still not clear. Pissarides and Wadsworth (1994) model the sequential decision of whether to search for a job, followed by the decision of whether to search while employed or unemployed. They compare employed people who search and who do not search, but do not assess differences between employed and unemployed job seekers. By focusing on employers' perceptions of their job applicants, the recruiting literature suggests that there might be important differences between unemployed and employed job applicants in terms of experience and qualifications (e.g. Atkinson et al. 1996).

There is evidence that current employment is strongly related to past unemployment even when allowing for observed and unobserved differences between individuals (Arulampalam et al. 2000; Gregg 2001). Such unemployment persistence indicates that employed and unemployed people have very different job and employment histories, which need to be incorporated into comparisons of employed and unemployed job seekers. Employed and unemployed job seekers may also differ in unobservable ways. For example, the unemployed may be less flexible than employed job seekers in terms of the jobs they find acceptable, either because they have higher reservation wages or because they have stricter requirements in terms of other job characteristics (e.g. occupation, permanency, etc.).

The level of competition between employed and unemployed job seekers may also vary over the business cycle. Empirical research tends to assume that on-the-job search falls during recessions, and competition for jobs is more likely to come from the unemployed in economic downturns than during periods of economic growth (Burgess 1993; Pissarides 1994). However, if employed and unemployed job seekers are different, there is no reason to assume that unemployed people will be more negatively affected by the presence of employed job seekers in periods of growth than in downturns. No single dataset allows analysis of all these questions. The quarterly Labour Force Survey (LFS) directly identifies employed workers engaging in on-the-job search, but has a very limited panel dimension. The British Household Panel Survey (BHPS) contains a long panel element but does not ask questions about on-the-job search activities. We use the quarterly LFS to identify (1) observable factors associated with the probability that employees engage in on-the-job search; and (2) whether employed and unemployed job seekers have similar individual characteristics, preferences over working hours, and job-search strategies. We then combine the quarterly LFS with the BHPS to identify (3) the impact of differences in past employment histories on the employment status of job seekers and (4) to account for unobserved individual-specific heterogeneity. Finally, we combine the quarterly and annual LFS to have 
a sufficiently long time-series to analyse (5) differences between unemployed and employed job seekers over the business cycle.

We find that unemployed and employed job seekers differ significantly in their individual characteristics, past employment histories, preferences over working hours, and job-search strategies, and that such differences persist over the business cycle. Our evidence is consistent with a no-pay low-pay cycle where workers become locked in a sequence of unemployment and low quality jobs. We conclude that in contrast to the assumptions made in the theoretical literature, the unemployed are unlikely to directly compete with employed job seekers.

\section{THEORETICAL BACKGROUND}

While many theoretical models of job search assume that employed and unemployed job seekers are substitutes and apply to the same vacancies (e.g. Burdett and Mortensen 1998; van den Berg and Ridder 1998) others indirectly suggest otherwise. For example Pissarides (1994) characterises the labour market by 'good' and 'bad' jobs, where employed job seekers only apply for and accept jobs that are better than their current one. The unemployed are more likely to be hired in 'bad' jobs and to engage in on-the-job search after accepting the 'bad' job. Consequently 'good' jobs should be filled by employed people who do not engage in on-the-job search, 'bad' jobs should be filled by employed people looking for a 'good' job, and the unemployed should mostly apply to 'bad' jobs. Employed and unemployed job seekers do not directly compete with each other, as they apply to different types of jobs.

There are other reasons why employed and unemployed job seekers may not directly compete with each other. Unemployment is higher among people with low rather than high education, and the probability of on-the-job search also varies with education (Pissarides and Wadsworth 1994). If employed job seekers have high levels of education, while the unemployed have low levels of education, they are unlikely to apply to the same vacancies. Furthermore, the literature on unemployment persistence suggests that current employment is strongly related to past unemployment (e.g. Arulampalam et al. 2000; Gregg 2001), even when allowing for observed and unobserved differences between individuals. Hence, unemployed and employed are also likely to have very different job and employment histories. Furthermore, employed and unemployed job seekers may differ in other unobservable ways, for example in terms of the jobs they find acceptable.

Less is known about characteristics of jobs sought, or search methods used. Van Ours (1995) argues that employers introduce competition between employed and unemployed job 
seekers by using different recruitment channels for the same vacancy, while Gorter et al. (1993) and Lindeboom et al. (1994) find that the use of particular recruitment channels reduces the probability that the vacancy is filled by an unemployed job applicant. Weber and Mahringer (2008) find self-selection among job seekers in terms of search methods and that the effectiveness of different methods is related to the labour market status of the job seeker.

Even when applying for the same jobs, if employed job seekers are preferred to the unemployed because of, for example, more occupation-specific human capital (Rosholm and Svarer 2004), differences in the quality of jobs obtained may be partly due to differences in previous experience. Employers may interpret unemployment as a negative signal, thus partly explaining differences in outcomes. Unemployed job seekers are recruited into low quality jobs with a high rate of destruction, resulting in unstable employment trajectories and repeated spells of unemployment (Böheim and Taylor 2002; Stewart 2007). However, there is more scope to discriminate against the unemployed in periods of growth when unemployment is low, while discrimination is harder in periods of recession when most job seekers are unemployed. Also high-quality workers may lose their job during recessions, raising the average quality of unemployed job seekers. If so we expect differences between employed and unemployed job seekers to fall, and competition between them to increase, in periods of recession. If only employed job seekers with the highest probability of finding a job search during a recession, the average quality of employed job seekers will increase, and differences between employed and unemployed job seekers will persist over the business cycle. Employed and unemployed job seekers will then never directly compete with each other.

\section{DATA}

We use data from the LFS and the BHPS, each of which have strengths and weaknesses. In particular, the LFS collects detailed information on job search behaviour by the employed and unemployed, while the BHPS is a panel dataset that collects information on employment histories.

The LFS is a nationally representative household survey which collects data on a large number of individual and household characteristics, focussing in particular on employment status, education, and job characteristics. It has been collected annually from 1984 to 1991 and quarterly since $1992 .{ }^{3}$ We use data up to the fourth quarter of 2009 . The advantage of the LFS is that it asks questions on job search to both employed and unemployed respondents.

\footnotetext{
${ }^{3}$ Although LFS data were collected biannually between 1975 and 1983, we use only data from 1984 onwards as prior to 1984 unemployment was not defined according to the ILO standard.
} 
This allows us to compare observed characteristics of employees who do and do not search for a new job, as well as of employed and unemployed job seekers. Although there are comparability issues between the annual and quarterly data, the questions on job search activities were similar over time. However, fewer details about the type of job sought were asked before 1992 .

We define job seekers in the LFS as those who: (1) are looking for paid employment; (2) have looked for work in the last four weeks; and (3) mention at least one method of job search. We focus on men and women of working age (16-59/64) who are either employed or unemployed. The self-employed, people in government training programs, unpaid family workers and inactive people (about $6 \%$ of all job seekers), and the small proportion (less than $1 \%$ ) of unemployed people who do not satisfy the three conditions are excluded from our analysis. The quarterly LFS data have a rotating panel structure in which people are interviewed for up to five successive quarters. To avoid repeated observations per individual, in most models we only use data from the first interview within the quarterly panel structure (to avoid problems of attrition); the exception is in models analysing the determinants of onthe-job search for which we only use data from the fifth interview (when questions are asked on wages).

The BHPS is a nationally representative panel of households living in the UK, in which each household member is interviewed annually. The survey started in 1991 and the most recent wave available to date refers to 2007. Our BHPS analysis also focuses on people of working age (16-59/64) who are employed or unemployed. The BHPS has two advantages over the LFS. Firstly it collects job and employment histories, allowing us to identify differences in previous employment experiences between employed and unemployed job seekers. It collects retrospective information on job and (un)employment spells that individuals experience between two waves of data (or in the previous 12 months). We use this to identify previous changes in occupation and unemployment and inactivity spells. Secondly it is a panel dataset, allowing us to account for unobserved differences across individuals in estimation. Although it includes a large quantity of information on individual, household and job characteristics, like many datasets the BHPS collects data on job search activity only from people who are currently unemployed.

As we do not directly observe job search among the employed in the BHPS, we use information in the quarterly LFS to construct a model of job search which we use to predict job search among employees in the BHPS. This step only uses job characteristics that are available - and comparable - in both datasets. Current wages are likely to be key 
determinants of engaging in on-the-job search and this is only available in the LFS from 1993 onwards. Therefore this part of our analysis is restricted to the period 1993-2007.

\section{DESCRIPTIVE STATISTICS}

Figure 1 shows the proportion of employees in the LFS who are looking for a job. The right panel shows the quarterly data, and the left shows the annual series, in which the 1992-2009 quarters are aggregated by calendar year. In a given year or quarter, between $5 \%$ and $7 \%$ of employees engage in on-the-job search, consistent with Pissarides and Wadsworth (1994). This proportion remains stable over time, and its variation does not coincide with the business cycle. This casts doubt on the common assumption that on-the-job search increases in periods of growth and falls in a recession (Mumford and Smith 1999; Anderson and Burgess 2000).

\section{FIGURE 1 ABOUT HERE}

Figure 2 shows the proportion of job seekers who are employed. This varies from $30 \%$ to more than $50 \%$ and more clearly follows variations in the business cycle: a larger proportion of job seekers are employed in periods of growth. As Figure 1 suggests that the proportion of employed people engaging in on-the-job search varies little over time, changes in the proportion of job seekers who are employed are mostly due to changes in unemployment.

\section{FIGURE 2 ABOUT HERE}

Table 1 summarises job search status of LFS respondents. The quarterly and annual series are broadly consistent and show that between $5 \%$ and $7 \%$ of employed workers look for a job, with no difference between men and women. The quarterly series (top panel) suggests that most job seekers are either unemployed or employed looking for a new - rather than additional - job. Women are more likely than men to look for an additional job. While among men the majority of job seekers are unemployed, among women most are employed. The longer time series in the bottom panel shows that the majority of job seekers are unemployed, particularly among men. 
Table 2 shows clear differences between types of job seekers in terms of preferences over working hours. $84 \%$ of employed job seekers looking for a new job prefer a full-time job, while $75 \%$ of prefer a part-time one. Among the unemployed, 25\% prefer a part-time job, $57 \%$ prefer a full-time job, while $18 \%$ are indifferent between the two.

\section{TABLE 2 ABOUT HERE}

Job seekers also differ in terms of the main job search method used. Responding to advertisements is the main method of $65 \%$ of employed job seekers looking for a new job, $52 \%$ of employed job seekers looking for an additional job, and $45 \%$ of unemployed people. A larger proportion of unemployed than employed job seekers use job centres, career offices, and job clubs (34\% compared with 15\%). Direct approach to employers is used by $8 \%$ and $14 \%$ of employed job seekers looking for a new and additional job respectively; similar proportions ask friends or relatives. Among the unemployed, about 10\% directly approach employers, while fewer than $9 \%$ ask friends or relatives.

\section{TABLE 3 ABOUT HERE}

These descriptives suggest differences between employed and unemployed job seekers in terms of the type o job sought and search methods used, which we now investigate more rigorously.

\section{MODELLING STRATEGY}

Our estimation strategy involves six distinct steps. The first examines factors associated with employees engaging in on-the-job search, while the second examines factors associated with being an employed rather than an unemployed job seeker. In the third step we examine whether employed and unemployed job seekers look for the same types of job (part- or fulltime), and use the same main method of search. These models are estimated using the quarterly series of the LFS from 1992 to 2009.

We then analyse whether differences in observable characteristics between unemployed and employed job seekers persist after controlling for employment histories and unobserved individual-specific characteristics, which involves the combination of the BHPS and LFS. Therefore the fourth step is to identify job seekers in the BHPS from models 
estimated using LFS data, and the fifth is to use this information to model the employment status of job seekers incorporating employment histories and unobserved individual-specific characteristics. Finally, the sixth step is to establish whether or not these patterns vary over the business cycle by combining the annual and quarterly LFS.

\section{WHO SEARCHES ON THE JOB?}

We first examine factors associated with employees engaging in on-the-job search. Pissarides (1994) suggests that workers who engage in on-the-job search are in worse jobs, with lower wages and less permanent positions than those who do not search. If so then differences between employed and unemployed job seekers do not merely reflect differences between employed and unemployed people in general. To analyse the determinants of searching onthe-job we use a multinomial probit model conditional on being employed. We model, via the latent variable $y_{i t}^{*}$, the probability of employees being in one of three mutually exclusive states $j: 0=$ not searching; $1=$ searching for a new job; $2=$ searching for an additional job:

$$
y_{i t}^{*}=X_{i}^{\prime} \beta_{1 j}+W_{i}^{\prime} \beta_{2 j}+\beta_{3 j} N E_{i}+\beta_{4 j} P E_{i}+\varepsilon_{i j}
$$

where $\varepsilon_{i j}$ are i.i.d. and follow a multivariate normal distribution. The probability of observing individual $i$ in state $q$ is the probability that $y_{i q}>y_{i j}$ for each $j \neq q$.

Explanatory variables include both individual $\left(X_{i}\right)$ and job $\left(W_{i}\right)$ characteristics. Individual characteristics include age, household structure and education. Job characteristics include employment type (temporary or permanent), sector (private or public), occupation, job tenure, wages and hours worked. The models also include two variables aggregated at the regional level: ${ }^{4}$ the quarterly change in the number of employees in the region $\left(N E_{i}\right)$, and the proportion of job seekers that are employed in the quarter and region $\left(P E_{i}\right)$. These capture local labour market conditions which we expect to influence the decision to engage in on-thejob search. Region, year and quarter identifiers are also included.

\section{DIFFERENCES BETWEEN EMPLOYED AND UNEMPLOYED JOB SEEKERS}

We analyse factors associated with being an employed rather than an unemployed job seeker using a multinomial probit model conditional on search. We model the probability that the job seeker is in one of three mutually exclusive states $j: 1=$ employed looking for a new job;

\footnotetext{
${ }^{4}$ Regional variations are important, Robson (2001) suggests that regional differences in the outflow from unemployment are mostly due to differences in the relative competitiveness of unemployed job seekers rather than in regional variations in hirings.
} 
$2=$ employed looking for an additional job; 3 = unemployed looking for a job; via the latent variable $z_{i t}^{*}$ :

$$
z_{i t}^{*}=X_{i}^{\prime} \alpha_{1 j}+\alpha_{2 j} N E_{i}+\xi_{i j}
$$

where $\xi_{i j}$ are i.i.d. and follow a multivariate normal distribution. The probability of observing individual $i$ in status $q$ is the probability that $z_{i q}>z_{i j}$ for each $j \neq q$. Explanatory variables include individual characteristics and the quarterly change in the number of employees in the region. 5

\section{PREFERENCES AND SEARCH BEHAVIOUR OF EMPLOYED AND UNEMPLOYED JOB SEEKERS}

If employed and unemployed job seekers have different job preferences they are unlikely to directly compete for the same jobs. We investigate whether they have similar preferences in terms of working hours using a multinomial probit model in which the dependent variable distinguishes between three states: $1=$ preference for a full-time job, $2=$ preference for a part-time job, or $3=$ no preference, via the latent variable $p_{i j}^{*}$ :

$$
p_{i t}^{*}=X_{i}^{\prime} \gamma_{1 j}+\gamma_{2 j} N J_{i}+\gamma_{3 j} A J_{i}+\eta_{i j}
$$

where $\eta_{i j}$ are i.i.d. and follow a multivariate normal distribution. The probability of observing individual $i$ having preference $q$ is the probability that $p_{i q}>p_{i j}$ for each $j \neq q$. Explanatory variables include the individual characteristics. Differences between job seekers are captured using variables identifying whether a respondent is employed looking for a new job $\left(N J_{i}\right)$ or employed looking for an additional job $\left(A J_{i}\right)$, with unemployed being the reference group.

A similar model is used to identify whether employed and unemployed job seekers use the same search methods. If they use different methods which have different levels of effectiveness, those using the least effective method will be disadvantaged in their job search. Alternatively, if different types of jobs are advertised using different methods, the choice of search method might be related to the type of job sought. Our dependent variable distinguishes between five search methods: $1=$ job centre, careers office or private employment agency; 2 = direct approach to employers; 3 = ask friends and relatives; $4=$ do anything else; with $5=$ advertising and answering adverts in newspapers etc. as the reference group. ${ }^{6}$ This is modelled via the latent variable $m_{i j}^{*}$ :

\footnotetext{
${ }^{5}$ Since we are not interested in the outcome of the search, search intensity is not relevant in this context.

${ }^{6}$ Using the internet to search for a job is not one of the possible options. It is likely that people using the internet classify this as 'advertising and answering adverts in newspapers' or in the group 'do anything else'.
} 


$$
m_{i t}^{*}=X_{i}^{\prime} \delta_{1 j}+\delta_{2 j} N J_{i}+\delta_{3 j} A J_{i}+\mu_{i j}
$$

where $\mu_{i j}$ are i.i.d. and follow a multivariate normal distribution. The probability of observing individual $i$ using search method $q$ is the probability that $m_{i q}>m_{i j}$ for each $j \neq q$.

\section{IDENTIFYING EMPLOYED JOB SEEKERS IN THE BHPS}

We next incorporate employment histories and individual-specific unobserved effects into our analysis using BHPS data. Employed job seekers are not directly identified in the BHPS. Therefore we predict who among employed BHPS respondents are most likely to engage in on-the-job search using models estimated on LFS data from 1993 to 2009. Given the random, nationally representative nature of both data sets, it seems reasonable to assume that the relationship between on-the-job search and job characteristics estimated using the LFS sample can also be applied to respondents in the BHPS sample. We estimate a probit model for engaging in on-the-job search similar to equation (1) using the LFS sample. The dependent variable distinguishes between employed people not searching and employed people searching for a new job. Explanatory variables that are available and comparable in both datasets include whether the job is temporary, part-time, in the public sector, occupation dummies, job tenure, weekly earnings, and hours of work. ${ }^{7}$ The model also includes the proportion of job seekers who are employed by quarter and region to capture local labour market conditions. Region, year and quarter identifiers are also included.

We use estimates from this model to predict the probability that each employed respondent in the BHPS engages in on-the-job search. As shown in Figure 1, about $6 \%$ of employees engage in on-the-job search and this varies little over the business cycle. Therefore for each year we identify employed job seekers in the BHPS as those $6 \%$ of respondents with the highest probability of engaging in on-the-job search.

\section{THE IMPACT OF EMPLOYMENT HISTORIES ON JOB SEARCH}

Having identified the group of employed job seekers in the BHPS, we next examine the impact of past employment histories on the probability of being an unemployed rather than an employed job seeker. We account for individual unobserved heterogeneity by estimating a random effects logit model, and relax the typical (and restrictive) assumption of independence between observed characteristics and unobservables by including within-

\footnotetext{
${ }^{7}$ Sensitivity analyses show that excluding individual characteristics from the model does not reduce its predictive power. While job tenure is likely to be endogenous, we use this purely to identify BHPS respondents most likely to engage in on-the-job rather than to identify causal effects.
} 
individual means of the time-varying covariates (Mundlak 1978). We model the probability that the job seeker is unemployed $(j=1)$ rather than employed $(j=0)$ at time $t$ via the latent variable $U_{i t}^{*}$ :

$$
U_{i t}^{*}=x_{i t}^{\prime} \beta+\bar{x}_{i}^{\prime} \gamma+u_{i}+v_{i t}
$$

where $U_{i t}^{*}$ denotes the unobservable propensity for the job seeker to be unemployed at time $t$, and $x$ is a vector of observable characteristics that influence $U_{i t}^{*}$. A job seeker is observed in unemployment when his/her propensity to be unemployed is greater than zero. $\bar{x}_{i}$ refers to the vector of individual means of time-varying covariates over time, $u_{i}$ denotes the individual-specific unobservable effects and $v$ is a random error, which is i.i.d. and follows a logistic distribution. Explanatory variables in $x$ include age, household structure and education, region and year identifiers, plus a set of variables summarising the previous (un)employment and job history of the job seeker. These capture whether or not the job seeker had an unemployment or inactivity spell in the previous 12 months (distinguishing between spells that were shorter and longer than 3 months), variables capturing earlier unemployment or inactivity spells that lasted longer than three months; and recent and earlier occupational change.

We identify BHPS respondents engaging in on-the-job search with error. At the extreme none of the employees we identify as job seekers will engage in on-the-job search, and our models would compare employment histories of employed and unemployed people. Therefore differences between employed and unemployed job seekers may be overestimated if employed job seekers are more similar than the employed who do not search to unemployed people. We check the robustness of our results to different definitions of employed job seekers, one of which identifies job seekers within the BHPS as people who move from job to job within the following 12 months without an intervening employment interruption (and who therefore must have engaged in some form of on-the-job search).

\section{DIFFERENCES OVER THE BUSINESS CYCLE}

Finally, to estimate whether differences between employed and unemployed job seekers vary over the business cycle, we combine the annual and the quarterly series of the LFS by grouping the quarterly data into years and keeping one observation per individual. We then re-estimate equations (2) and (4) separately for periods when unemployment rates were increasing and decreasing. This allows us to identify whether the unemployment stock is 
more similar to that of employed job seekers in economic downtowns than in periods of economic growth. Periods of increasing unemployment include 1984, 1991, 1992, 1993, and the years between 2005 and 2009; all other years are classified as periods of falling unemployment. ${ }^{8}$ Model specifications differ slightly from those described previously because of inconsistencies over time in data availability.

\section{EMPIRICAL RESULTS}

\section{DETERMINANTS OF ON-THE-JOB SEARCH}

Table 4 presents results from models of the determinants of being an employed job seeker (equation (1)), estimated separately for men and women using LFS data from 1993-2009. Consistent with the literature, the probability of engaging in on-the-job search falls with wages and job tenure. Earning $£ 10$ more per hour is associated with a reduction of two percentage points in the probability of engaging in on-the-job search. Ten more years of job tenure reduces the probability by three percentage points for men and two percentage points for women. On-the-job search is also more likely among older workers (although this relationship is non-linear). Married women are two percentage points less likely than single women to look for a new job, and 0.4 percentage points less likely to look for an additional job, but marriage reduces these probabilities by only 0.5 and 0.08 percentage points for men. Dependent children reduce on-the-job search but only for women. For both men and women, the probability of looking for a new (but not an additional) job increases with education.

\section{TABLE 4 ABOUT HERE}

Having a temporary job increases the probability of looking for a new job by between four and five percentage points, while men in part-time jobs are more likely than those in full-time jobs to look for a new or additional job. This suggests that the part-time job is unsatisfactory in terms of labour supply preferences, and is consistent with non-standard

\footnotetext{
${ }^{8}$ We also estimated the models separately for periods with high or low - rather than increasing or decreasing unemployment. If we use as a threshold an unemployment rate of 7\%, then we classify the years between 1998 and 2008 as periods of low unemployment, and all the remaining years (from 1984 to 1997, plus 2009) as periods of high unemployment. The results are not sensitive to such changes in the definition of business cycles. It can also be argued that the most recent recession is essentially different from previous ones as it is the first in which the UK has a flexible labour market. We have estimated the models using the quarterly data, and excluding previous recessions. Here the period of decreasing unemployment runs from the first quarter of 1994 to the second quarter of 2005, while the period of increasing unemployment runs from the third quarter of 2005 to the most recent quarter. Again, the estimated regression coefficients change only marginally from those presented.
} 
forms of employment such as part-time and temporary jobs being 'bad' jobs (McGovern et al. 2004). Workers may accept part-time jobs to escape unemployment, even though they preferred a full-time job. ${ }^{9}$

Public sector employees are less likely than those in the private sector to look for a new job but more likely to look for an additional job. Working more hours is associated with a lower probability of looking for an additional job and, for women, a higher probability of looking for a new job. The probability of on-the-job search is independent of total employment, although more (fewer) men look for a new (additional) job when a larger proportion of job seekers are employed.

These results suggest that, consistent with theory, workers engaging in on-the-job search are in worse jobs than those not searching. They have lower wages and are more likely to be in temporary or part-time work. ${ }^{10}$

\section{FACTORS ASSOCIATED WITH THE EMPLOYMENT STATUS OF JOB SEEKERS}

Table 5 presents estimates of factors associated with being an employed rather than an unemployed job seeker (equation (2)). The results show that the unemployed are on average younger than employed job seekers looking for a new job, although the relationship is nonlinear. The probability of being an employed rather than an unemployed job seeker is higher if married (by 18 percentage points for men and 8 percentage points for women), and increases with education (by up to 40 percentage points). The latter is consistent with studies of recruitment behaviour, which find that one of the reasons why the unemployed do not get a particular job is that they do not meet the job requirements in terms of qualification and experience levels (e.g. Gorter et al. 1993; Behrenz 2001). Dependent children reduce the probability of being an employed job seeker by 15 percentage points for women. These factors have a larger impact on the probability of being an employee searching for a new rather than an additional job relative to being unemployed. In terms of education, for example, men with the highest levels of education (NVQ level 4 and above) are 39 percentage points more likely to be employed and looking for a new job rather than

\footnotetext{
${ }^{9}$ Descriptive statistics from the LFS are consistent with this: $18 \%$ of unemployed people who were looking for a full-time job accepted a part-time job, while $12 \%$ of those looking for a part-time job accepted a full-time job. Less than $10 \%$ of job-to-job movers were looking for full-time work but accepted a part-time job, while $19 \%$ of those looking for a part-time job accepted a full-time job.

${ }^{10}$ Results in Table 4 are robust to changes in model specification. For example excluding job tenure (which is potentially endogenous) has only a small impact on the estimated coefficients. Using a one quarter lag of the proportion of job seekers who are employed, or excluding the variable altogether, has no impact on the estimates.
} 
unemployed than those with no qualifications, and women 36 percentage points more likely. However they are just one percentage point more likely to be employees looking for an additional job rather than unemployed.

\section{TABLE 5 ABOUT HERE}

\section{PREFERENCES IN WORKING HOURS}

Table 6 presents results from modelling the impact of being an employed and unemployed job seeker on preferences over working hours (equation (3)). Since education has a large impact on the employment status of job seekers, we estimate models of work hour preferences (and of search methods used) separately by education. For brevity, we only present the marginal effects on the variables of interest, which identify the type of job seeker.

The estimated effects are similar across levels of education. Employees looking for a new job have a strong preference for full-time jobs, such men are between 13 and 19 percentage points more likely than unemployed men to prefer a full-time job (25-30 percentage points among women). In contrast employees looking for an additional job are more likely than unemployed job seekers to prefer a part-time job, and less likely to prefer a full-time job. Being unemployed increases the probability of having no preference between part- and full-time jobs (the reference category), which suggests that the unemployed may be more likely than employees to apply for and accept 'bad' jobs, and therefore not be in direct competition. $^{11}$

\section{TABLE 6 ABOUT HERE}

Descriptive statistics on job-to-job transitions from the LFS provide further support for this conclusion. The unemployed are more likely than job-to-job movers to enter a temporary or a part-time job (34\% for a temporary and $41 \%$ for a part-time job compared with $23 \%$ and 20\%). They are also more likely to engage in on-the-job search in the new job (15\% compared with $8.5 \%$ ). This is in line with Booth et al. (2002) who find that, though undesirable, temporary jobs are stepping stones to better jobs.

\footnotetext{
${ }^{11}$ We have investigated if these differences vary with length of search. Adding interaction terms between search duration and the type of job seeker shows no clear pattern. (These results are available from the authors on request.) This is cross-sectional data and so we are unable to disentangle whether differences between people who search for different lengths of time are due to adaptation to circumstances or are the results of selfselection.
} 


\section{DIFFERENCES IN JOB SEARCH METHODS}

Table 7 shows the impact of being an employed rather than unemployed job seeker on the main search method used, again estimated separately by education level. Results indicate that employed job seekers are less likely than the unemployed to use job centres, career offices or job clubs. However these differences are smaller for more highly educated job seekers (with at least NVQ Level 4) than for less educated job seekers (10 percentage points for men and women with the highest education compared to 30 percentage points for men and 15-20 percentage points for women with no education). Among highly educated job seekers, the employed looking for an additional job are more likely than the unemployed to directly approach potential employers, ask friends and relatives, and do 'anything else'. Although we have no information on search intensity, this suggests that unemployed people rely more on employment agencies and formal job search channels rather than engaging in proactive job search behaviour.

These estimates also suggest that differences in search methods used by employed and unemployed job seekers are smaller for women than for men, thus indicating that direct competition between employed and unemployed job seekers is higher for women than men.

\section{TABLE 7 ABOUT HERE}

\section{INTRODUCING EMPLOYMENT HISTORIES AND UNOBSERVED INDIVIDUAL-SPECIFIC EFFECTS}

We now extend the analysis to introduce previous employment experiences and unobserved individual-specific effects. The first stage is to identify employed job seekers in the BHPS by estimating models of on-the-job search using LFS data and applying the estimated coefficients to BHPS respondents. The impact of job characteristics on the probability of engaging in on the-job search, estimated using the LFS, is shown in Table 8. These are largely consistent with those in Table 4 , and for brevity are not discussed here. ${ }^{12}$

\section{TABLE 8 ABOUT HERE}

We use these estimated coefficients to predict who among employed BHPS respondents are most likely to engage in on-the-job search. The individual probability of

\footnotetext{
${ }^{12}$ The only notable difference between Tables 4 and 8 is that the impact of part-time shifts from positive to zero for men and from zero to negative for women.
} 
engaging in on-the-job search varies over time, not only because of potential changes in the characteristics of the job but also because of the macroeconomic climate captured in the model by year and quarter identifiers and the proportion of job seekers who are employed by quarter and region.

The predicted probabilities of BHPS respondents engaging in on-the-job search range from almost zero to a maximum of $27 \%$, with a median of $4.5 \%$ (Figure 3). Such low predicted probabilities are not surprising, given that the LFS data indicate that only $6 \%$ of employed people engage in on-the-job search. For each year of BHPS data we rank men and women according to their predicted probability of being an employed job seeker, and categorise as employed job seekers the $6 \%$ of employees with the highest probability. Hence the threshold probability used to identify employed job seekers varies by year, and ranges from $8 \%$ to $11 \%$. Table 9 shows how the threshold probability varies over time, and the corresponding BHPS sample sizes.

\section{FiguRe 3 ABOUT HERE}

\section{TABLE 9 ABOUT HERE}

Table 10 compares individual characteristics of employees searching and not searching in the LFS with employees in the BHPS that we define as searching and not searching. For comparison the characteristics of the unemployed in the BHPS are also included. The average characteristics of men and women identified as employed job seekers and non-seekers in the two surveys are similar. For example employed job seekers are on average younger than non-seekers and are less likely to be married. They are also better educated. Table 10 also indicates that in the BHPS sample unemployed people have lower levels of education than employed people; this is especially true for men.

\section{TABLE 10 ABOUt HeRE}

In this table we also make an initial comparison of previous experiences of unemployment and economic inactivity between employed and unemployed job seekers and employed people who do not engage in on-the-job search using BHPS data. This indicates that employed job seekers are more likely to have experienced unemployment or inactivity 
spells in the previous 12 months; these spells have also been longer. ${ }^{13}$ Employed job seekers are also more likely to have had occupational changes in the past, perhaps indicating a less stable employment trajectory. The unemployed are more likely than the others to have experienced earlier unemployment spells, and less likely to have experienced previous occupational changes, and have employment histories that are between those of employed people not searching and employed people searching for a new job.

To analyse the role played by unobserved individual heterogeneity and past employment histories in shaping differences between employed and unemployed job seekers, we initially estimate a logit model pooling observations over the years. Table 11 presents odds ratios, so that an estimated effect of less than (more than) one indicates that the characteristics reduces (increases) the probability of a job seeker being unemployed. The results, shown in column (i), are consistent with our previous analysis. Married people are less likely than single people to be unemployed rather than employed job seekers. The probability of being an unemployed rather than employed job seeker is lower for the more highly educated.

The results of random effect logit models which incorporate time-invariant unobserved effects are shown in column (ii). Although some of the individual characteristics (such as age and marital status) lose their explanatory power, the impact of the level of education remains statistically significant. Therefore education affects the probability of being an unemployed rather than employed job seeker even when accounting for unobserved individual characteristics. This could be related to the lower probability of highly qualified people experiencing unemployment. We examine this in column (iii), which adds information on employment histories. However the estimates on the education variables in column (iii) are very similar to those in column (ii), indicating that the impact of education is not related to differences in employment histories of people with different educational outcomes. It is clear that education still plays a statistically - and economically - significant role.

The coefficients on the previous labour market experience variables show that past experiences of unemployment reduce the probability that the job seeker is unemployed rather than employed: those who had an unemployment spell in the past are more likely to be currently employed and seeking a new job. This is consistent with the idea that there is some turnover in unemployment: the unemployed are able to find a job, but then keep searching while in the new job. Those who did not experience unemployment are likely to be employed

\footnotetext{
13 Although note that the unemployed here includes a small proportion of long-term unemployed, who cannot have had another recent spell of unemployment or economic inactivity.
} 
people who are not searching (see also below). The table also shows that - at least for women - the impact on the status of job seekers of longer unemployment spells is larger than the impact of shorter unemployment spells, and that earlier spells are less important than recent ones. A recent inactivity spell increases the probability that a male job seeker is unemployed rather than employed. This may indicate that men move from economic inactivity into unemployment and then from unemployment into a (bad) job in which they keep searching for a new (good) job. Once again, longer spells have larger impacts than shorter spells. Earlier spells of inactivity have negative effects for both men and women: people who had an inactivity spell more than one year ago are more likely to be employed job seekers rather than unemployed job seekers. For men, recent occupational changes increase the probability that the job seeker is unemployed rather than employed, thus suggesting and unstable career path, while previous occupational changes are not statistically significant. ${ }^{14}$

\section{TABLE 11 AbOut HeRE}

\section{SENSITIVITY CHECKS}

The validity of our results relies crucially on our ability to accurately identify employed people in the BHPS who engage in on-the-job search. Failure to do so results in models that simply compare the unemployed with the employed. As robustness checks, we compare results using different strategies to identify on-the-job search, shown in Table 12. For comparison, the first two columns report estimates from the last two columns of Table 11, where employed job seekers are defined as the $6 \%$ of employed people in the BHPS with the highest probability of engaging in on-the-job search. The remaining columns of the table present results from first changing the threshold from 6\% to $15 \%$ (column (ii)); and secondly of moving the threshold from $15 \%$ to $100 \%$ and comparing all employed people to the unemployed (column (iii)).

A comparison of the estimates across columns indicates that the coefficients on individual characteristics do change, and some gain statistical significance in column (iii). The impact of qualifications changes little when moving from column (i) to column (ii), but becomes much smaller in column (iii). Hence the differences identified in column (i) and discussed previously are genuine differences between unemployed and employed job seekers

\footnotetext{
${ }^{14}$ As education is a key factor determining whether the job seeker is unemployed or employed, we have reestimated the models separately by qualification level. Results confirm the main findings of Table 11. For all qualification levels previous unemployment significantly reduces the probability of being an unemployed job seeker, recent inactivity increases it, while earlier inactivity reduces it.
} 
(rather than between employed and unemployed people), suggesting that employees searching for a new job are more similar to unemployed people than to employees who do not search. For example, they might have higher risk of losing their job and have low chances to find a 'good' job (and therefore to become employed not searching). Also the impacts of previous unemployment spells are smaller when we move from column (i) to column (iii), while the effect of inactivity remains.

\section{TABLE 12 ABOUt HeRE}

It seems reasonable to assume that employed people who move between jobs without any intervening spell of non-employment were searching while in their previous job. An alternative way to identify employed job seekers is therefore to use job-to-job moves with no intervening non-employment. Although job-to-job moves can be identified from the BHPS, this only identifies those who are successful in their search (i.e. people who subsequently experience a job-to-job move). This may be a highly selected group of all employees who engage in on-the-job search. The models comparing successful employed job seekers to the unemployed are in column (iv) of Table 12, and the results are more consistent with those in column (iii) than those in columns (i) and (ii). The only difference is in the role of occupational changes, which increase the probability of moving from job-to-job relative to being unemployed. Generally however the similarity of the estimates in columns (iii) and (iv) suggests that job-to-job moves are not a good way to identify employed people engaging in on-the-job search; at least when interviews are one year apart.

\section{DIFFERENCES OVER THE BUSINESS CYCLE}

Our final contribution is to use the combined annual and quarterly LFS to examine whether differences between employed and unemployed job seekers vary over the business cycle. Table 13 presents estimates from probit models comparing individual characteristics of employed and unemployed job seekers, where the dependent variable takes the value one if the job seeker is employed and zero if unemployed. Table 14 presents estimates from models of search method used. These are estimated for the whole period (1984-2009), and separately for the sub-periods of increasing and decreasing unemployment.

The results in Table 13 are consistent with those using quarterly data in Table 5. The probability of being an employed rather than unemployed job seeker increases with age (at a declining rate), with education and with marriage (although the effect is not statistically 
significant for women). Job seekers with no qualifications are more likely to be unemployed rather than employed. This again confirms the low degree of substitution between unemployed and employed job seekers. Although estimates suggest that differences between employed and unemployed job seekers in terms of education are smaller in periods of increasing than in periods of decreasing unemployment, these are marginal.

\section{TABLE 13 ABOUT HERE}

In terms of job search methods used, the results in Table 14 are consistent with those using the quarterly data (Table 7). Employees looking for a new job are more likely than the unemployed to answer advertisements in newspapers etc., and do anything else, and less likely to use all other methods. Estimates do vary in periods of decreasing and increasing unemployment - differences between employed and unemployed job seekers in search method used are generally lower in periods of increasing than falling unemployment. However such differences are small.

TABLE 14 ABOUT HERE

Results suggest that differences between employed and unemployed job seekers are marginally smaller during recessions but they remain statistically significant. The persistence in differences over the business cycle suggests that the low degree of substitution between employed and unemployed of job seekers does not change with economic conditions or with the stock of unemployed. ${ }^{15}$

\section{CONCLUSIONS}

We use the data from the LFS from 1984 to 2009 and from the BHPS 1991 to 2007 to analyse the extent to which employed and unemployed job seekers have similar individual characteristics (including employment histories), preferences over working hours, and job

\footnotetext{
${ }^{15}$ The comparison of consecutive quarters in the LFS suggests that the proportion of employees who start searching is similar in periods of growth and recession. However in periods of recession fewer employees stop searching (e.g. because they found a better job), and a larger proportion keep searching in both quarters. Similarly in periods of recession a smaller proportion of the unemployed move into work (from which to engage in on-the-job search) while a larger proportion remains unemployed. If only the best candidates find a suitable job, we can conclude that the average quality of employed and unemployed job seekers changes in the same direction. Both in periods of growth and recession, the unemployed are in a different market and therefore do not compete with employed job seekers.
} 
search strategies. The job search literature suggests that competition with employed job seekers reduces the job opportunities available to the unemployed, and assumes that both have similar individual characteristics and apply to the same jobs.

Our initial analysis suggests that employed job seekers are in worse jobs than employees who do not search. There is some evidence that the unemployed apply to and accept different (worse) jobs than employed job seekers, but then keep searching for better opportunities once employed. We also find significant differences in the characteristics of job seekers. For example, the more highly educated are much more likely to be employed rather than unemployed job seekers (even when accounting for individual-specific unobserved effects) and, conditional on the level of education, employed and unemployed job seekers also have different preferences in terms of working hours. Employees looking for a new job have much stronger preferences toward full-time jobs than the unemployed. This is consistent with the unemployed having lower expectations in terms of job sought than employees, and suggests that employed and unemployed job seekers are unlikely to be close substitutes and to apply to similar jobs. Employed and unemployed job seekers also use different search methods. These differences do not change substantially over the business cycle.

Employed and unemployed job seekers also have different employment histories. Our results suggest that the unemployed transit into 'bad' jobs from which they keep looking for a 'good' job. Employed job seekers might have accepted job offers which were not ideal in order to exit unemployment, and are likely to engage in on-the-job search when in the new job. However, job seekers who search for a new job also seem to be in unstable jobs, with few chances to find a 'good' job and therefore to stop searching. Such people might be locked in a sequence of unemployment and bad jobs (a low-pay no-pay cycle), while others, with comparatively worse individual characteristics, might never find a job at all.

Contrary to what often assumed in the literature, we find evidence that employed and unemployed job seekers are systematically different and unlikely to be directly in competition with each other. As a result, job search activities of employees are unlikely to affect unemployed job seekers. 


\section{REFERENCES}

Anderson, P.M. and Burgess, S.M. (2000) Empirical Matching Functions: Estimation and Interpretation Using State-Level Data. The Review of Economic and Statistics 82(1): 93-102.

Andrews, M.J., Bradley, S. and Upward, R. (2001) Estimating the Probability of a Match Using Microeconomic Data for the Youth Labour Market. Labour Economics 8: 335357.

Arulampalam, W., Booth, A.L. and Taylor, M.P. (2000) Unemployment Persistence. Oxford Economic Papers 52(1): 24-50.

Atkinson, J., Giles, L. and Meager, N. (1996) Employers, Recruitment and the Unemployed, Institute for Employment Studies Report 325.

Blau, D.M. and Robins, P.K. (1990) Job Search Outcomes for the Employed and Unemployed. Journal of Political Economy 98(3): 637-655.

Booth, A.L., Francesconi, M. and Frank, J. (2002) Temporary Jobs: Stepping Stones or Dead Ends? The Economic Journal 112(480): F189-F213.

Burdett, K. and Mortensen, D.T. (1998) Wage Differentials, Employer Size, and Unemployment. International Economic Review 39(2): 257-273.

Burgess, S.M. (1993) A Model of Competition between Unemployed and Employed Job Searchers: An Application to the Unemployment Outflow Rate in Britain. The Economic Journal 103(420): 1190-1204.

Eriksson, S. and Gottfries, N. (2005) Ranking of Job Applicants, on-the-Job Search, and Persistent Unemployment. Labour Economics 12: 407-428.

Eriksson, S. and Lagerstrom, J. (2006) Competition between Employed and Unemployed Job Applicants: Swedish Evidence. Scandinavian Journal of Economics 108(3): 373-396.

Gorter, C., Nijkamp, P. and Rietveld, P. (1993) The Impact of Employers' Recruitment Behaviour on the Allocation of Vacant Jobs to Unemployed Job Seekers. Empirical Economics 18(2): 251-269.

Gregg, P. (2001) The Impact of Youth Unemployment on Adult Unemployment in the Ncds. The Economic Journal 111(475): F626-F653.

Lindeboom, M., van Ours, J.C. and Renes, G. (1994) Matching Employers and Workers: An Empirical Analysis on the Effectiveness of Search. Oxford Economic Papers 46(1): 45-67.

McGovern, P., Smeaton, D. and Hill, S. (2004) Bad Jobs in Britain: Nonstandard Employment and Job Quality. Work and Occupations 31(2): 225-249.

Mumford, K. and Smith, P.N. (1999) The Hiring Function Reconsidered: On Closing the Circle. Oxford Bulletin of Economics and Statistics 61(3): 343-364.

Mundlak, Y. (1978) On the Pooling of Time Series and Cross Section Data. Econometrica 46(1): 69-85.

Pissarides, C.A. (1994) Search Unemployment with on-the-Job Search. Review of Economic Studies 61: 457-475.

Pissarides, C.A. and Wadsworth, J. (1994) On-the-Job Search. Some Empirical Evidence from Britain. European Economic Review 38: 385-401.

Robson, M.T. (2001) Regional Variations in the Competitiveness of Unemployed JobSeekers and the Rate of Outflows from Unemployment. Oxford Bulletin of Economics and Statistics 63(1): 61-90.

Rogerson, R., Shimer, R. and Wright, R. (2005) Search-Theoretic Models of the Labor Market: A Survey. Journal of Economic Literature 43(December): 959-988.

Rosholm, M. and Svarer, M. (2004) Endogenous Wage Dispersion in a Search-Matching Model. Labour Economics 11: 623-645. 
van den Berg, G.J. and Ridder, G. (1998) An Empirical Equilibrium Search Model of the Labor Market. Econometrica 66(5): 1183-1221.

van Ours, J.C. (1995) An Empirical Note on Employed and Unemployed Job Search. Economics Letters 49: 447-452.

Weber, A. and Mahringer, H. (2008) Choice and Success of Job Search Methods. Empirical Economics 35: 153-178. 


\section{TABLES AND FIGURES}

TABLE 1

PROPORTION OF PEOPLE SEARCHING FOR A JOB, LFS 1984-2009; 1992-2009

\begin{tabular}{lrrrr}
\hline Quarterly Data (1992-2009) & \multicolumn{3}{c}{ Men } & \multicolumn{2}{c}{ Women } \\
\hline Employed not searching & 93.68 & & 93.54 & \\
Employed searching new job & 5.98 & 42.54 & 5.78 & 47.63 \\
Employed searching additional job & 0.33 & 2.38 & 0.67 & 5.56 \\
Unemployed searching & & 55.08 & & 46.81 \\
\cline { 2 - 6 } Total & 100 & 100 & 100 & 100 \\
\hline Annual Data (1984-2009) & 94.09 & & & \\
\hline Employed not searching & 5.91 & 40.49 & 6.33 & 48.03 \\
Employed searching a job & & 59.51 & & 51.97 \\
Unemployed searching & 100 & 100 & 100 & 100 \\
Total & & & & \\
\hline
\end{tabular}

"Others" are self-employed, people in government training programmes or unpaid family workers

TABLE 2

PREFERENCES OVER WORKING HOURS BY EMPLOYMENT STATUS, LFS 1992-2009

\begin{tabular}{|c|c|c|c|c|}
\hline Preference for: & $\begin{array}{c}\text { Employed } \\
\text { looking for new job }\end{array}$ & $\begin{array}{c}\text { Employed } \\
\text { looking for additional job }\end{array}$ & Unemployed & Total \\
\hline Full-time (\%) & 83.71 & 17.95 & 56.73 & 66.26 \\
\hline Part-time (\%) & 12.1 & 74.46 & 24.85 & 21.73 \\
\hline No preference $(\%)$ & 4.2 & 7.59 & 18.42 & 12.01 \\
\hline Observations & 35,028 & 3,728 & 45,235 & 83,991 \\
\hline Total & 100 & 100 & 100 & 100 \\
\hline
\end{tabular}

TABLE 3

JOB SEARCH METHODS BY EMPLOYMENT STATUS, LFS 1992-2009

\begin{tabular}{lrrrr}
\hline Job search method: & $\begin{array}{c}\text { Employed } \\
\text { looking for } \\
\text { new job }\end{array}$ & $\begin{array}{c}\text { Employed } \\
\text { looking for } \\
\text { additional job }\end{array}$ & Unemployed & Total \\
\hline Job centre, careers office, job club & 14.05 & 15.69 & 33.53 & 24.61 \\
Advertising, answering ads in newspapers & 65.24 & 52.00 & 44.77 & 53.63 \\
Direct approach to employers & 7.80 & 13.78 & 10.27 & 9.4 \\
Ask friends and relatives & 7.89 & 13.73 & 8.79 & 8.64 \\
Do anything else & 5.01 & 4.8 & 2.65 & 3.73 \\
\hline Total & 35,030 & 3,729 & 45,240 & 83,999 \\
& 100 & 100 & 100 & 100 \\
\hline
\end{tabular}


TABLE 4

DETERMINANTS OF ON-THE-JOB SEARCH, LFS 1993-2009

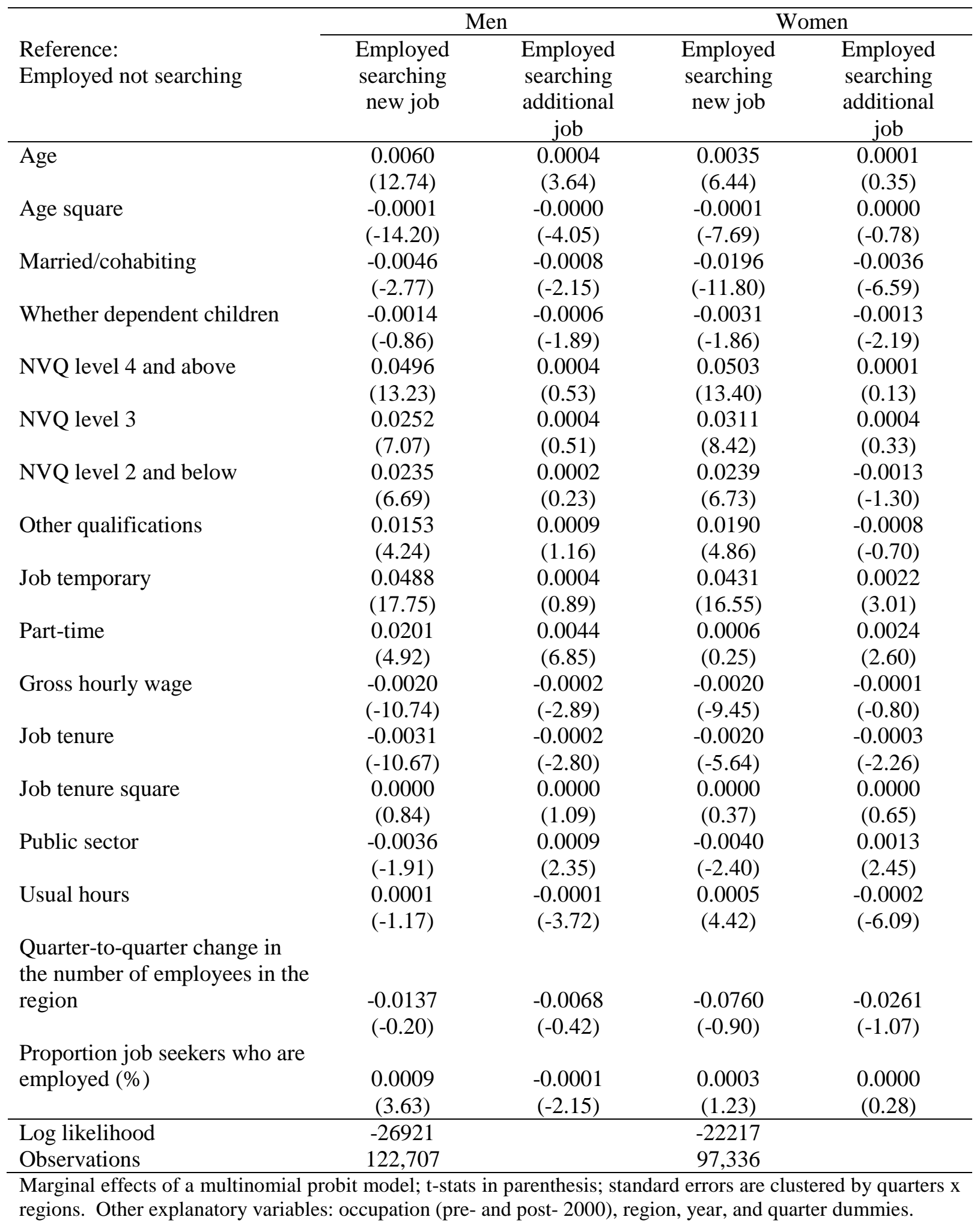


TABLE 5

DIFFERENCES BETWEEN EMPLOYED AND UNEMPLOYED JOB SEEKERS, LFS 1992-2009

\begin{tabular}{lcccc}
\hline \multirow{2}{*}{ Base: Unemployed searching job } & \multicolumn{2}{c}{ Men } & \multicolumn{2}{c}{ Women } \\
\cline { 2 - 5 } & $\begin{array}{c}\text { Employed } \\
\text { searching } \\
\text { new job }\end{array}$ & $\begin{array}{c}\text { Employed } \\
\text { searching } \\
\text { additional } \\
\text { job }\end{array}$ & $\begin{array}{c}\text { Employed } \\
\text { searching } \\
\text { new job }\end{array}$ & $\begin{array}{c}\text { Employed } \\
\text { searching } \\
\text { additional } \\
\text { job }\end{array}$ \\
\hline Age & 0.034 & -0.001 & 0.034 & -0.002 \\
Age square & $(31.98)$ & $(3.11)$ & $(24.13)$ & $(-2.38)$ \\
Married/cohabiting & -0.000 & 0.000 & -0.000 & 0.000 \\
Whether dependent children & $(-36.45)$ & $(2.48)$ & $(-23.81)$ & $(2.96)$ \\
NVQ level 4 and above & 0.182 & 0.002 & 0.077 & -0.004 \\
NVQ level 3 & $(32.22)$ & $(1.11)$ & $(13.61)$ & $(-1.60)$ \\
NVQ level 2 and below & -0.038 & 0.002 & -0.146 & 0.015 \\
& $(-8.24)$ & $(1.40)$ & $(-29.61)$ & $(6.30)$ \\
Other qualifications & 0.389 & 0.011 & 0.356 & 0.010 \\
Quarter-to-quarter change in the & $(59.12)$ & $(4.42)$ & $(46.68)$ & $(2.67)$ \\
number of employees in the region & 0.274 & 0.010 & 0.255 & 0.016 \\
& $(38.32)$ & $(4.25)$ & $(29.20)$ & $(3.91)$ \\
& 0.221 & 0.006 & 0.204 & 0.006 \\
Log likelihood & $(32.94)$ & $(2.68)$ & $(28.43)$ & $(1.63)$ \\
Observations & 0.158 & 0.008 & 0.127 & 0.007 \\
\hline
\end{tabular}

Marginal effects of a multinomial probit model; t-stats in parenthesis; standard errors are clustered by quarters $\mathrm{x}$ regions. Other explanatory variables: region, year and quarter dummies. 
TABLE 6

PREFERENCES OVER WORKING HOURS, LFS 1992-2009

\begin{tabular}{|c|c|c|c|c|}
\hline $\begin{array}{l}\text { Base: No preference } \\
\text { between part- and full time }\end{array}$ & $\begin{array}{l}\text { Looking for } \\
\text { full-time job }\end{array}$ & $\begin{array}{l}\text { Looking for } \\
\text { part-time job }\end{array}$ & $\begin{array}{l}\text { Looking for } \\
\text { full -time job }\end{array}$ & $\begin{array}{l}\text { Looking for } \\
\text { part-time job }\end{array}$ \\
\hline NVQ level 4 and above & \multicolumn{2}{|c|}{ Men $(\mathrm{N}=9,929)$} & \multicolumn{2}{|c|}{ Women $(\mathrm{N}=9,136)$} \\
\hline Employed searching new job & $\begin{array}{c}0.126 \\
(21.45)\end{array}$ & $\begin{array}{l}-0.040 \\
(-9.02)\end{array}$ & $\begin{array}{c}0.228 \\
(27.65)\end{array}$ & $\begin{array}{c}-0.130 \\
(-15.75)\end{array}$ \\
\hline Employed searching add. job & $\begin{array}{c}-0.151 \\
(-12.41) \\
\end{array}$ & $\begin{array}{c}0.135 \\
(19.52)\end{array}$ & $\begin{array}{c}-0.263 \\
(-11.92)\end{array}$ & $\begin{array}{c}0.310 \\
(17.21) \\
\end{array}$ \\
\hline NVQ level 3 & \multicolumn{2}{|c|}{ Men $(\mathrm{N}=10,435)$} & \multicolumn{2}{|c|}{ Women $(\mathrm{N}=6,544)$} \\
\hline Employed searching new job & $\begin{array}{c}0.178 \\
(23.75)\end{array}$ & $\begin{array}{c}-0.071 \\
(-12.60)\end{array}$ & $\begin{array}{c}0.301 \\
(30.98)\end{array}$ & $\begin{array}{c}-0.202 \\
(-19.24)\end{array}$ \\
\hline Employed searching add. job & $\begin{array}{l}-0.226 \\
(-12.82)\end{array}$ & $\begin{array}{c}0.201 \\
(18.42)\end{array}$ & $\begin{array}{l}-0.231 \\
(-9.20)\end{array}$ & $\begin{array}{c}0.289 \\
(13.39)\end{array}$ \\
\hline NVQ level 2 and below & \multicolumn{2}{|c|}{ Men $(\mathrm{N}=12,649)$} & \multicolumn{2}{|c|}{ Women $(\mathrm{N}=13,830)$} \\
\hline Employed searching new job & $\begin{array}{l}0.181 \\
(23.66)\end{array}$ & $\begin{array}{l}-0.051 \\
(-8.85)\end{array}$ & $\begin{array}{c}0.272 \\
(38.80)\end{array}$ & $\begin{array}{c}-0.154 \\
(-20.52)\end{array}$ \\
\hline Employed searching add. job & $\begin{array}{l}-0.289 \\
(-15.39)\end{array}$ & $\begin{array}{c}0.283 \\
(24.60)\end{array}$ & $\begin{array}{l}-0.259 \\
(-12.03)\end{array}$ & $\begin{array}{c}0.330 \\
(16.83)\end{array}$ \\
\hline Other qualifications & \multicolumn{2}{|c|}{ Men $(N=6,709)$} & \multicolumn{2}{|c|}{ Women $(\mathrm{N}=5,231)$} \\
\hline Employed searching new job & $\begin{array}{c}0.178 \\
(16.87)\end{array}$ & $\begin{array}{l}-0.040 \\
(-6.49)\end{array}$ & $\begin{array}{c}0.287 \\
(24.53)\end{array}$ & $\begin{array}{c}-0.144 \\
(-12.07)\end{array}$ \\
\hline Employed searching add. job & $\begin{array}{l}-0.237 \\
(-9.66)\end{array}$ & $\begin{array}{c}0.215 \\
(18.78)\end{array}$ & $\begin{array}{l}-0.236 \\
(-7.58)\end{array}$ & $\begin{array}{c}0.323 \\
(11.19)\end{array}$ \\
\hline No qualifications & \multicolumn{2}{|c|}{ Men $(\mathrm{N}=10,319)$} & \multicolumn{2}{|c|}{ Women $(\mathrm{N}=6,961)$} \\
\hline Employed searching new job & $\begin{array}{c}0.194 \\
(14.82)\end{array}$ & $\begin{array}{l}-0.020 \\
(-2.95)\end{array}$ & $\begin{array}{c}0.236 \\
(18.49)\end{array}$ & $\begin{array}{l}-0.115 \\
(-8.24)\end{array}$ \\
\hline Employed searching add. job & $\begin{array}{l}-0.279 \\
(-9.59)\end{array}$ & $\begin{array}{c}0.219 \\
(18.81)\end{array}$ & $\begin{array}{l}-0.234 \\
(-7.37)\end{array}$ & $\begin{array}{c}0.298 \\
(10.01)\end{array}$ \\
\hline
\end{tabular}

Marginal effects of a multinomial probit model; $t$-stats in parenthesis; standard errors are clustered by quarters $\mathrm{x}$ regions. Other explanatory variables: age, dummies for married/cohabiting, singles, presence of dependent children in the household, region, year and quarter. 
TABLE 7

JOB SEARCH METHOD, LFS 1992-2009

\begin{tabular}{|c|c|c|c|c|c|c|c|c|}
\hline $\begin{array}{l}\text { Base: } \\
\text { Advertising and answering } \\
\text { ads in newspapers }\end{array}$ & $\begin{array}{c}\text { Job centre } \\
\text { Careers office } \\
\text { Job club } \\
\end{array}$ & $\begin{array}{c}\text { Direct } \\
\text { approach } \\
\text { to employers }\end{array}$ & $\begin{array}{l}\text { Ask friends } \\
\text { and relatives }\end{array}$ & $\begin{array}{l}\text { Do } \\
\text { anything } \\
\text { else }\end{array}$ & $\begin{array}{c}\text { Job centre } \\
\text { Careers office } \\
\text { Job club } \\
\end{array}$ & $\begin{array}{c}\text { Direct } \\
\text { approach } \\
\text { to employers }\end{array}$ & $\begin{array}{l}\text { Ask friends } \\
\text { and relatives }\end{array}$ & $\begin{array}{c}\text { Do } \\
\text { anything } \\
\text { else } \\
\end{array}$ \\
\hline & \multicolumn{4}{|c|}{ Men NVQ level 4 and above; N=9,929 } & \multicolumn{4}{|c|}{ Women NVQ level 4 and above; $N=9,139$} \\
\hline \multirow[t]{2}{*}{ Employed searching new job } & -0.106 & -0.021 & -0.005 & 0.034 & -0.086 & -0.017 & 0.001 & 0.026 \\
\hline & $(12.36)$ & $(-3.46)$ & $(-0.86)$ & $(4.98)$ & $(-12.03)$ & $(-2.59)$ & $(0.19)$ & $(3.74)$ \\
\hline \multirow[t]{3}{*}{ Employed searching add. job } & -0.099 & 0.051 & 0.048 & 0.042 & -0.045 & 0.043 & 0.025 & 0.035 \\
\hline & $(-3.76)$ & $(3.44)$ & $(3.65)$ & $(2.48)$ & $(-2.72)$ & $(3.49)$ & $(2.35)$ & $(2.55)$ \\
\hline & \multicolumn{4}{|c|}{ Men NVQ level 3; N=10,438 } & \multicolumn{4}{|c|}{ Women NVQ level 3; N=6545 } \\
\hline \multirow[t]{2}{*}{ Employed searching new job } & -0.195 & -0.026 & 0.004 & 0.026 & -0.120 & -0.039 & -0.010 & 0.026 \\
\hline & $(-23.00)$ & $(-4.27)$ & $(0.58)$ & $(5.89)$ & $(-12.64)$ & $(-5.15)$ & $(-1.56)$ & $(4.30)$ \\
\hline \multirow[t]{3}{*}{ Employed searching add. job } & -0.116 & 0.001 & 0.056 & 0.013 & -0.149 & 0.014 & 0.015 & 0.031 \\
\hline & $(-4.47)$ & $(0.07)$ & $(2.96)$ & $(0.96)$ & $(-7.23)$ & $(0.89)$ & $(1.22)$ & $(2.81)$ \\
\hline & \multicolumn{4}{|c|}{ Men NVQ level 2 and below; $N=12,696$} & \multicolumn{4}{|c|}{ Women NVQ level 2 and below; $\mathrm{N}=13,833$} \\
\hline \multirow[t]{2}{*}{ Employed searching new job } & -0.240 & 0.004 & 0.026 & 0.038 & -0.146 & -0.011 & 0.010 & 0.026 \\
\hline & $(-29.23)$ & $(0.82)$ & $(4.86)$ & $(8.75)$ & $(-19.76)$ & $(-2.07)$ & $(2.15)$ & $(6.46)$ \\
\hline \multirow[t]{3}{*}{ Employed searching add. job } & -0.251 & 0.056 & 0.043 & 0.033 & -0.157 & 0.024 & 0.058 & 0.043 \\
\hline & $(-9.44)$ & $(4.25)$ & $(2.73)$ & $(2.87)$ & $(-9.69)$ & $(2.48)$ & $(7.33)$ & $(5.79)$ \\
\hline & \multicolumn{4}{|c|}{ Men Other qualifications; $\mathrm{N}=6,711$} & \multicolumn{4}{|c|}{ Women Other qualifications; $\mathrm{N}=5,235$} \\
\hline \multirow[t]{2}{*}{ Employed searching new job } & -0.276 & 0.003 & 0.025 & 0.028 & -0.159 & -0.008 & & 0.029 \\
\hline & $(-23.22)$ & $(0.44)$ & $(2.78)$ & $(5.91)$ & $(-12.29)$ & $(-1.02)$ & & $(4.86)$ \\
\hline \multirow[t]{3}{*}{ Employed searching add. job } & -0.294 & 0.033 & 0.069 & 0.033 & -0.149 & -0.009 & & 0.008 \\
\hline & $(-7.90)$ & $(1.56)$ & $(2.64)$ & $(2.44)$ & $(-5.34)$ & $(-0.54)$ & & $(0.65)$ \\
\hline & \multicolumn{4}{|c|}{ Men No qualifications; $\mathrm{N}=10,320$} & \multicolumn{4}{|c|}{ Women No qualifications; $\mathrm{N}=6,962$} \\
\hline \multirow[t]{2}{*}{ Employed searching new job } & -0.311 & 0.011 & 0.049 & 0.021 & -0.171 & 0.008 & & 0.019 \\
\hline & $(-25.46)$ & $(1.54)$ & $(5.96)$ & $(5.50)$ & $(-13.56)$ & $(1.00)$ & & $(3.86)$ \\
\hline \multirow[t]{2}{*}{ Employed searching add. job } & -0.341 & 0.041 & 0.106 & 0.016 & -0.148 & 0.015 & & 0.018 \\
\hline & $(-7.54)$ & $(1.93)$ & $(4.31)$ & $(1.35)$ & $(-5.78)$ & $(0.92)$ & & $(1.82)$ \\
\hline
\end{tabular}

Marginal effects of a multinomial probit model; t-stats in parenthesis; standard errors are clustered by quarters $\mathrm{x}$ regions. Other explanatory variables: age, dummies for married/cohabiting, singles, presence of dependent children in the household, region, year and quarter. 
TABLE 8

DETERMINANTS OF ON-THE-JOB SEARCH, LFS 1993-2007

\begin{tabular}{|c|c|c|c|c|}
\hline & \multicolumn{2}{|c|}{$\begin{array}{l}(1) \\
\text { Men }\end{array}$} & \multicolumn{2}{|c|}{$\begin{array}{c}(2) \\
\text { Women }\end{array}$} \\
\hline & Coefficients & $\begin{array}{l}\text { Marginal } \\
\text { effects }\end{array}$ & Coefficients & $\begin{array}{c}\text { Marginal } \\
\text { effects }\end{array}$ \\
\hline Job temporary & $\begin{array}{c}0.437 \\
(17.47)\end{array}$ & $\begin{array}{c}0.048 \\
(17.18)\end{array}$ & $\begin{array}{c}0.416 \\
(17.01)\end{array}$ & $\begin{array}{c}0.045 \\
(16.96)\end{array}$ \\
\hline Part-time & $\begin{array}{l}0.047 \\
(1.19)\end{array}$ & $\begin{array}{l}0.005 \\
(1.19)\end{array}$ & $\begin{array}{l}-0.075 \\
(-3.09)\end{array}$ & $\begin{array}{l}-0.008 \\
(-3.08)\end{array}$ \\
\hline Gross weekly pay (hundreds) & $\begin{array}{l}-0.041 \\
(-9.48)\end{array}$ & $\begin{array}{l}-0.005 \\
(-9.47)\end{array}$ & $\begin{array}{l}-0.048 \\
(-8.25)\end{array}$ & $\begin{array}{l}-0.005 \\
(-8.18)\end{array}$ \\
\hline Years of job tenure / 10 & $\begin{array}{l}-0.277 \\
(-10.77)\end{array}$ & $\begin{array}{l}-0.031 \\
(-10.69)\end{array}$ & $\begin{array}{l}-0.319 \\
(-10.51)\end{array}$ & $\begin{array}{c}-0.034 \\
(-10.48)\end{array}$ \\
\hline Years of job tenure / 10 squared & $\begin{array}{l}-0.017 \\
(-1.63)\end{array}$ & $\begin{array}{l}-0.002 \\
(-1.63)\end{array}$ & $\begin{array}{l}0.024 \\
(1.71)\end{array}$ & $\begin{array}{l}0.003 \\
(1.71)\end{array}$ \\
\hline Public sector & $\begin{array}{l}-0.006 \\
(-0.33)\end{array}$ & $\begin{array}{l}-0.001 \\
(-0.33)\end{array}$ & $\begin{array}{l}-0.024 \\
(-1.46)\end{array}$ & $\begin{array}{l}-0.003 \\
(-1.46)\end{array}$ \\
\hline Usual hours per week / 10 & $\begin{array}{l}0.007 \\
(0.79)\end{array}$ & $\begin{array}{l}0.001 \\
(0.79)\end{array}$ & $\begin{array}{l}0.077 \\
(7.59)\end{array}$ & $\begin{array}{l}0.008 \\
(7.60)\end{array}$ \\
\hline $\begin{array}{l}\text { Proportion job seekers who are } \\
\text { employed }(\%)\end{array}$ & $\begin{array}{l}0.008 \\
(3.37)\end{array}$ & $\begin{array}{l}0.001 \\
(3.36)\end{array}$ & $\begin{array}{l}0.006 \\
(2.02)\end{array}$ & $\begin{array}{l}0.001 \\
(2.03)\end{array}$ \\
\hline $\begin{array}{l}\text { Pseudo } \mathrm{R}^{2} \\
\text { Observations }\end{array}$ & $\begin{array}{c}0.052 \\
119,398\end{array}$ & & $\begin{array}{c}0.034 \\
94,053\end{array}$ & \\
\hline
\end{tabular}

Probit model; dependent variable $=1$ if the employee is searching for a new job, and zero otherwise. T-stats in parenthesis; standard errors are clustered by quarters x regions. Other explanatory variables: dummies for occupations (pre- and post- 2000), regions, year, and quarter.

TABLE 9

THRESHOLD PROBABILITY OF ENGAGING IN ON-THE-JOB SEARCH, BHPS 1993-2007

\begin{tabular}{ccccc}
\hline Year & $\begin{array}{c}\text { Threshold } \\
\text { Probability (\%) }\end{array}$ & $\begin{array}{c}\text { Employed not searching } \\
\text { (observations) }\end{array}$ & $\begin{array}{c}\text { Employed searching } \\
\text { (observations) }\end{array}$ & $\begin{array}{c}\text { Unemployed } \\
\text { (observations) }\end{array}$ \\
\hline 1993 & 9.14 & 3838 & 246 & 546 \\
1994 & 10.30 & 3919 & 251 & 508 \\
1995 & 10.70 & 3878 & 248 & 392 \\
1996 & 11.32 & 4081 & 261 & 393 \\
1997 & 11.14 & 4654 & 298 & 408 \\
1998 & 9.86 & 4650 & 297 & 365 \\
1999 & 9.90 & 6388 & 408 & 588 \\
2000 & 10.77 & 6362 & 407 & 568 \\
2001 & 9.50 & 6352 & 406 & 514 \\
2002 & 9.42 & 5637 & 360 & 424 \\
2003 & 8.86 & 5514 & 353 & 458 \\
2004 & 8.77 & 5343 & 342 & 371 \\
2005 & 8.29 & 5284 & 338 & 407 \\
2006 & 9.22 & 5379 & 344 & 409 \\
2007 & 8.74 & 5130 & 328 & 322 \\
\hline
\end{tabular}


TABLE 10

INDIVIDUAL CHARACTERISTICS, BHPS AND LFS 1993-2007

\begin{tabular}{|c|c|c|c|c|c|c|c|c|c|c|}
\hline \multirow[b]{2}{*}{ Dataset: } & \multicolumn{2}{|c|}{$\begin{array}{c}\text { Employed men } \\
\text { not searching }\end{array}$} & \multicolumn{2}{|c|}{$\begin{array}{l}\text { Employed men } \\
\text { searching }\end{array}$} & \multirow{2}{*}{$\begin{array}{c}\text { Unemployed } \\
\text { men } \\
\text { BHPS }\end{array}$} & \multicolumn{2}{|c|}{$\begin{array}{l}\text { Employed women } \\
\text { not searching }\end{array}$} & \multicolumn{2}{|c|}{$\begin{array}{l}\text { Employed women } \\
\text { searching }\end{array}$} & \multirow{2}{*}{$\begin{array}{c}\text { Unemployed } \\
\text { women } \\
\text { BHPS }\end{array}$} \\
\hline & LFS & BHPS & LFS & BHPS & & LFS & BHPS & LFS & BHPS & \\
\hline age & 39.13 & 38.67 & 34.17 & 31.12 & 34.12 & 38.06 & 37.95 & 33.70 & 30.50 & 33.33 \\
\hline Married & 0.605 & 0.749 & 0.473 & 0.471 & 0.486 & 0.579 & 0.718 & 0.404 & 0.505 & 0.419 \\
\hline Children 0-15 & 0.380 & 0.401 & 0.377 & 0.299 & 0.391 & 0.397 & 0.405 & 0.376 & 0.356 & 0.409 \\
\hline Degree & 0.190 & 0.173 & 0.244 & 0.189 & 0.088 & 0.158 & 0.162 & 0.235 & 0.263 & 0.094 \\
\hline Higher qualification & 0.108 & 0.336 & 0.116 & 0.258 & 0.186 & 0.138 & 0.298 & 0.136 & 0.228 & 0.181 \\
\hline GCE, A levels and lower & 0.608 & 0.382 & 0.578 & 0.472 & 0.431 & 0.578 & 0.428 & 0.560 & 0.459 & 0.477 \\
\hline Other or no qualification & 0.095 & 0.109 & 0.063 & 0.082 & 0.296 & 0.127 & 0.113 & 0.068 & 0.050 & 0.248 \\
\hline Recent unemployment spell $<=3 \mathrm{~m}$ & & 0.019 & & 0.120 & 0.053 & & 0.019 & & 0.147 & 0.053 \\
\hline Recent unemployment spell $>3 \mathrm{~m}$ & & 0.018 & & 0.112 & 0.096 & & 0.016 & & 0.090 & 0.058 \\
\hline Recent inactivity spell $<=3 \mathrm{~m}$ & & 0.005 & & 0.026 & 0.023 & & 0.009 & & 0.062 & 0.027 \\
\hline Recent inactivity spell > 3m & & 0.016 & & 0.115 & 0.092 & & 0.053 & & 0.277 & 0.123 \\
\hline Recent occupational change & & 0.055 & & 0.183 & 0.086 & & 0.062 & & 0.209 & 0.083 \\
\hline Earlier unemployment spell $>3 \mathrm{~m}$ & & 0.037 & & 0.115 & 0.149 & & 0.027 & & 0.064 & 0.084 \\
\hline Earlier inactivity spell > 3m & & 0.032 & & 0.181 & 0.131 & & 0.095 & & 0.361 & 0.174 \\
\hline Earlier occupational change & & 0.092 & & 0.175 & 0.084 & & 0.095 & & 0.129 & 0.081 \\
\hline
\end{tabular}

These descriptive statistics refer to the samples only and are therefore unweighted 
TABLE 11

DETERMINANTS OF BEING AN UNEMPLOYED RATHER THAN EMPLOYED JOB SEEKER, BHPS 1993-2007

\begin{tabular}{|c|c|c|c|c|c|c|}
\hline & \multicolumn{2}{|c|}{$\begin{array}{c}\text { (i) } \\
\text { Logit model }\end{array}$} & \multicolumn{2}{|c|}{$\begin{array}{c}\text { (ii) } \\
\text { Random effect } \\
\text { Logit model }\end{array}$} & \multicolumn{2}{|c|}{$\begin{array}{c}\text { (iii) } \\
\text { Random effect } \\
\text { Logit model }\end{array}$} \\
\hline & Men & Women & Men & Women & Men & Women \\
\hline Age & $\begin{array}{l}1.027 \\
(1.48)\end{array}$ & $\begin{array}{c}0.968 \\
(-1.02)\end{array}$ & $\begin{array}{c}0.724 \\
(-1.71)\end{array}$ & $\begin{array}{c}0.759 \\
(-0.59)\end{array}$ & $\begin{array}{l}0.748 \\
(-1.49)\end{array}$ & $\begin{array}{l}0.765 \\
(-0.53)\end{array}$ \\
\hline Age square & $\begin{array}{l}1.000 \\
(-1.29)\end{array}$ & $\begin{array}{l}1.001 \\
(1.11)\end{array}$ & $\begin{array}{c}1.000 \\
(-0.55)\end{array}$ & $\begin{array}{c}0.998 \\
(-1.26)\end{array}$ & $\begin{array}{c}0.999 \\
(-0.71)\end{array}$ & $\begin{array}{l}0.997 \\
(-1.64)\end{array}$ \\
\hline Married & $\begin{array}{l}0.665 \\
(-4.77)\end{array}$ & $\begin{array}{c}0.684 \\
(-3.33)\end{array}$ & $\begin{array}{c}0.862 \\
(-0.67)\end{array}$ & $\begin{array}{c}0.507 \\
(-1.64)\end{array}$ & $\begin{array}{l}0.822 \\
(-0.87)\end{array}$ & $\begin{array}{l}0.533 \\
(-1.44)\end{array}$ \\
\hline Children 0-15 & $\begin{array}{l}1.506 \\
(5.77)\end{array}$ & $\begin{array}{c}0.966 \\
(-0.32)\end{array}$ & $\begin{array}{l}1.503 \\
(2.35)\end{array}$ & $\begin{array}{l}1.226 \\
(0.51)\end{array}$ & $\begin{array}{l}1.526 \\
(2.39)\end{array}$ & $\begin{array}{l}1.265 \\
(0.55)\end{array}$ \\
\hline First or higher degree & $\begin{array}{c}0.270 \\
(-10.55)\end{array}$ & $\begin{array}{c}0.157 \\
(-8.12)\end{array}$ & $\begin{array}{c}0.165 \\
(-9.13)\end{array}$ & $\begin{array}{l}0.055 \\
(-7.37)\end{array}$ & $\begin{array}{l}0.151 \\
(-9.47)\end{array}$ & $\begin{array}{l}0.057 \\
(-6.78)\end{array}$ \\
\hline Other higher qualif & $\begin{array}{l}0.377 \\
(-8.62)\end{array}$ & $\begin{array}{l}0.316 \\
(-5.37)\end{array}$ & $\begin{array}{c}0.250 \\
(-7.94)\end{array}$ & $\begin{array}{c}0.157 \\
(-5.36)\end{array}$ & $\begin{array}{l}0.258 \\
(-7.83)\end{array}$ & $\begin{array}{l}0.153 \\
(-5.07)\end{array}$ \\
\hline GCE, A levels, lower & $\begin{array}{c}0.434 \\
(-8.14)\end{array}$ & $\begin{array}{c}0.341 \\
(-5.30)\end{array}$ & $\begin{array}{c}0.306 \\
(-7.37)\end{array}$ & $\begin{array}{c}0.188 \\
(-5.23)\end{array}$ & $\begin{array}{c}0.318 \\
(-7.21)\end{array}$ & $\begin{array}{c}0.168 \\
(-5.18)\end{array}$ \\
\hline $\begin{array}{l}\text { Recent unemployment } \\
\text { spell }<=3 \mathrm{~m}\end{array}$ & & & & & $\begin{array}{c}0.439 \\
(-4.85)\end{array}$ & $\begin{array}{c}0.482 \\
(-2.06)\end{array}$ \\
\hline $\begin{array}{l}\text { Recent unemployment } \\
\text { spell > 3m }\end{array}$ & & & & & $\begin{array}{c}0.451 \\
(-5.48)\end{array}$ & $\begin{array}{c}0.239 \\
(-3.35)\end{array}$ \\
\hline $\begin{array}{l}\text { Recent inactivity spell } \\
<=3 \mathrm{~m}\end{array}$ & & & & & $\begin{array}{l}1.726 \\
(1.94)\end{array}$ & $\begin{array}{l}2.604 \\
(1.73)\end{array}$ \\
\hline $\begin{array}{l}\text { Recent inactivity spell } \\
>3 \mathrm{~m}\end{array}$ & & & & & $\begin{array}{l}2.451 \\
(3.92)\end{array}$ & $\begin{array}{l}2.094 \\
(1.70)\end{array}$ \\
\hline $\begin{array}{l}\text { Recent occupational } \\
\text { change }\end{array}$ & & & & & $\begin{array}{l}1.394 \\
(2.30)\end{array}$ & $\begin{array}{l}1.151 \\
(0.41)\end{array}$ \\
\hline $\begin{array}{l}\text { Earlier unemployment } \\
\text { spell > 3m }\end{array}$ & & & & & $\begin{array}{c}0.621 \\
(-3.36)\end{array}$ & $\begin{array}{l}0.903 \\
(-0.24)\end{array}$ \\
\hline $\begin{array}{l}\text { Earlier inactivity spell } \\
>3 \mathrm{~m}\end{array}$ & & & & & $\begin{array}{c}0.607 \\
(-2.30)\end{array}$ & $\begin{array}{l}0.343 \\
(-2.48)\end{array}$ \\
\hline $\begin{array}{l}\text { Earlier occupational } \\
\text { change }\end{array}$ & & & & & $\begin{array}{l}1.039 \\
(0.25)\end{array}$ & $\begin{array}{c}0.954 \\
(-0.13) \\
\end{array}$ \\
\hline Log likelihood & -3735 & -1388 & -3512 & -1335 & -3411 & -1292 \\
\hline Observations & 6,030 & 2,256 & 6,030 & 2,256 & 6,030 & 2,256 \\
\hline
\end{tabular}


TABLE 12

DETERMINANTS OF BEING AN UNEMPLOYED RATHER THAN EMPLOYED JOB SEEKER; SENSITIVITY ANALYSIS, BHPS 1993-2007

\begin{tabular}{|c|c|c|c|c|c|c|c|c|}
\hline & \multicolumn{2}{|c|}{$\begin{array}{l}\text { (i) } \\
6 \% \text { with highest probability } \\
\text { on-the-job search }\end{array}$} & \multicolumn{2}{|c|}{$\begin{array}{l}\text { (ii) } \\
15 \% \text { with highest probability } \\
\text { on-the-job search }\end{array}$} & \multicolumn{2}{|c|}{$\begin{array}{l}\text { (iii) } \\
\text { All employed people } \\
(100 \%)\end{array}$} & \multicolumn{2}{|c|}{$\begin{array}{c}\text { (iv) } \\
\text { Job-to-job moves } \\
\text { (BHPS) }\end{array}$} \\
\hline & Men & Women & Men & Women & Men & Women & Men & Women \\
\hline \multirow[t]{2}{*}{ Age } & 0.748 & 0.765 & 0.808 & 1.068 & 0.697 & 0.657 & 0.656 & 0.655 \\
\hline & $(-1.49)$ & $(-0.53)$ & $(-1.58)$ & $(0.27)$ & $(-3.19)$ & $(-3.07)$ & $(-10.81)$ & $(-10.17)$ \\
\hline \multirow[t]{2}{*}{ Age square } & 0.999 & 0.997 & 1.001 & 1.000 & 1.003 & 1.003 & 1.001 & 1.002 \\
\hline & $(-0.71)$ & $(-1.64)$ & $(1.90)$ & $(-0.46)$ & $(6.14)$ & $(5.86)$ & $(2.07)$ & $(4.09)$ \\
\hline \multirow[t]{2}{*}{ Married } & 0.822 & 0.533 & 0.783 & 0.667 & 0.719 & 0.704 & 0.719 & 0.694 \\
\hline & $(-0.87)$ & $(-1.44)$ & $(-1.54)$ & $(-1.65)$ & $(-2.65)$ & $(-2.76)$ & $(-2.22)$ & $(-2.73)$ \\
\hline \multirow[t]{2}{*}{ Children 0-15 } & 1.526 & 1.265 & 1.404 & 0.731 & 1.113 & 0.928 & 1.298 & 0.772 \\
\hline & $(2.39)$ & $(0.55)$ & $(2.62)$ & $(-1.31)$ & $(1.05)$ & $(-0.64)$ & $(2.14)$ & $(-2.13)$ \\
\hline \multirow[t]{2}{*}{ First or higher degree } & 0.151 & 0.057 & 0.144 & 0.142 & 0.248 & 0.334 & 0.295 & 0.423 \\
\hline & $(-9.47)$ & $(-6.78)$ & $(-12.25)$ & $(-9.11)$ & $(-9.89)$ & $(-7.47)$ & $(-8.48)$ & $(-5.72)$ \\
\hline \multirow[t]{2}{*}{ Other higher qualification } & 0.258 & 0.153 & 0.240 & 0.333 & 0.321 & 0.424 & 0.382 & 0.528 \\
\hline & $(-7.83)$ & $(-5.07)$ & $(-10.61)$ & $(-5.91)$ & $(-9.74)$ & $(-6.88)$ & $(-7.95)$ & $(-4.91)$ \\
\hline \multirow[t]{2}{*}{ GCE, A levels and lower } & 0.318 & 0.168 & 0.326 & 0.494 & 0.413 & 0.517 & 0.461 & 0.639 \\
\hline & $(-7.21)$ & $(-5.18)$ & $(-9.06)$ & $(-4.12)$ & $(-8.28)$ & $(-5.79)$ & $(-7.08)$ & $(-3.81)$ \\
\hline \multirow[t]{2}{*}{ Recent unemployment spell $<=3 \mathrm{~m}$} & 0.439 & 0.482 & 0.531 & 0.921 & 0.751 & 1.294 & 0.687 & 1.011 \\
\hline & $(-4.85)$ & $(-2.06)$ & $(-4.60)$ & $(-0.35)$ & $(-2.28)$ & $(1.71)$ & $(-2.57)$ & $(0.07)$ \\
\hline \multirow[t]{2}{*}{ Recent unemployment spell $>3 \mathrm{~m}$} & 0.451 & 0.239 & 0.479 & 0.439 & 0.655 & 0.496 & 0.692 & 0.645 \\
\hline & $(-5.48)$ & $(-3.35)$ & $(-6.31)$ & $(-3.48)$ & $(-4.06)$ & $(-4.45)$ & $(-2.85)$ & $(-2.57)$ \\
\hline \multirow[t]{2}{*}{ Recent inactivity spell $<=3 \mathrm{~m}$} & 1.726 & 2.604 & 1.840 & 1.563 & 2.358 & 2.079 & 1.833 & 2.002 \\
\hline & $(1.94)$ & $(1.73)$ & $(2.67)$ & $(1.25)$ & $(4.12)$ & $(3.42)$ & $(2.40)$ & $(3.04)$ \\
\hline \multirow[t]{2}{*}{ Recent inactivity spell $>3 \mathrm{~m}$} & 2.451 & 2.094 & 2.746 & 2.473 & 3.081 & 2.708 & 4.714 & 3.778 \\
\hline & $(3.92)$ & $(1.70)$ & $(5.57)$ & $(3.29)$ & $(6.68)$ & $(6.09)$ & $(7.29)$ & $(7.13)$ \\
\hline \multirow[t]{2}{*}{ Recent occupational change } & 1.394 & 1.151 & 1.332 & 1.429 & 1.692 & 1.564 & 1.951 & 2.103 \\
\hline & $(2.30)$ & $(0.41)$ & $(2.59)$ & $(1.69)$ & $(5.40)$ & $(3.89)$ & $(5.88)$ & $(6.04)$ \\
\hline Earlier unemployment spell $>3 \mathrm{~m}$ & 0.621 & 0.903 & 0.629 & 0.846 & 0.687 & 0.550 & 0.426 & 0.438 \\
\hline
\end{tabular}




\begin{tabular}{|c|c|c|c|c|c|c|c|c|}
\hline & $(-3.36)$ & $(-0.24)$ & $(-4.26)$ & $(-0.67)$ & $(-3.93)$ & $(-4.16)$ & $(-6.66)$ & $(-4.90)$ \\
\hline Earlier occupational change & $\begin{array}{l}1.039 \\
(0.25)\end{array}$ & $\begin{array}{c}0.954 \\
(-0.13)\end{array}$ & $\begin{array}{c}0.975 \\
(-0.23)\end{array}$ & $\begin{array}{l}1.308 \\
(1.28)\end{array}$ & $\begin{array}{c}0.923 \\
(-0.81)\end{array}$ & $\begin{array}{l}1.028 \\
(0.23)\end{array}$ & $\begin{array}{l}1.347 \\
(2.48)\end{array}$ & $\begin{array}{l}1.757 \\
(4.30)\end{array}$ \\
\hline \multirow[t]{2}{*}{ Observations } & -3411 & -1292 & -5060 & -2530 & -6586 & -4934 & -4390 & -3320 \\
\hline & 6,030 & 2,256 & 14,601 & 5,031 & 43,653 & 43,866 & 11,949 & 10,523 \\
\hline
\end{tabular}

time. 
TABLE 13

DIFFERENCES BETWEEN EMPLOYED AND UNEMPLOYED JOB SEEKERS OVER THE BUSINESS CYCLE, LFS 1984-2009

\begin{tabular}{|c|c|c|c|}
\hline Men & All years & $\begin{array}{c}\text { Decreasing } \\
\text { unemployment }\end{array}$ & $\begin{array}{c}\text { Increasing } \\
\text { unemployment }\end{array}$ \\
\hline Age & $\begin{array}{c}0.027 \\
(30.07)\end{array}$ & $\begin{array}{c}0.027 \\
(26.45)\end{array}$ & $\begin{array}{c}0.026 \\
(14.99)\end{array}$ \\
\hline Age square & $\begin{array}{c}-0.000 \\
(-36.12)\end{array}$ & $\begin{array}{c}-0.000 \\
(-32.02)\end{array}$ & $\begin{array}{c}-0.000 \\
(-17.92)\end{array}$ \\
\hline Married/cohabiting & $\begin{array}{c}0.145 \\
(35.75)\end{array}$ & $\begin{array}{c}0.149 \\
(30.58)\end{array}$ & $\begin{array}{c}0.136 \\
(18.84)\end{array}$ \\
\hline Degree or higher & $\begin{array}{c}0.415 \\
(75.10)\end{array}$ & $\begin{array}{c}0.427 \\
(63.07)\end{array}$ & $\begin{array}{c}0.385 \\
(41.90)\end{array}$ \\
\hline Lower qualifications & $\begin{array}{c}0.233 \\
(63.05)\end{array}$ & $\begin{array}{c}0.242 \\
(54.87)\end{array}$ & $\begin{array}{c}0.211 \\
(36.05)\end{array}$ \\
\hline Prop. job seekers employed (\%) & $\begin{array}{c}0.008 \\
(31.51)\end{array}$ & $\begin{array}{c}0.008 \\
(28.75)\end{array}$ & $\begin{array}{c}0.008 \\
(16.37)\end{array}$ \\
\hline $\begin{array}{l}\text { Log likelihood } \\
\text { Observations }\end{array}$ & $\begin{array}{l}-50939 \\
89,476 \\
\end{array}$ & $\begin{array}{l}-34721 \\
61,041 \\
\end{array}$ & $\begin{array}{l}-16184 \\
28,435 \\
\end{array}$ \\
\hline Women & All years & $\begin{array}{c}\text { Decreasing } \\
\text { unemployment }\end{array}$ & $\begin{array}{c}\text { Increasing } \\
\text { unemployment }\end{array}$ \\
\hline Age & $\begin{array}{c}0.024 \\
(23.30)\end{array}$ & $\begin{array}{c}0.026 \\
(20.31)\end{array}$ & $\begin{array}{c}0.021 \\
(11.96)\end{array}$ \\
\hline Age square & $\begin{array}{c}-0.000 \\
(-22.35)\end{array}$ & $\begin{array}{c}-0.000 \\
(-19.71)\end{array}$ & $\begin{array}{c}-0.000 \\
(-11.26)\end{array}$ \\
\hline Married/cohabiting & $\begin{array}{l}0.004 \\
(0.72)\end{array}$ & $\begin{array}{l}0.000 \\
(0.01)\end{array}$ & $\begin{array}{l}0.013 \\
(1.39)\end{array}$ \\
\hline Degree or higher & $\begin{array}{c}0.386 \\
(57.31)\end{array}$ & $\begin{array}{c}0.392 \\
(48.72)\end{array}$ & $\begin{array}{c}0.374 \\
(30.67)\end{array}$ \\
\hline Lower qualifications & $\begin{array}{c}0.202 \\
(44.59)\end{array}$ & $\begin{array}{c}0.203 \\
(36.72)\end{array}$ & $\begin{array}{c}0.196 \\
(25.53)\end{array}$ \\
\hline Prop. job seekers employed (\%) & $\begin{array}{c}0.008 \\
(17.95)\end{array}$ & $\begin{array}{c}0.008 \\
(15.54)\end{array}$ & $\begin{array}{c}0.009 \\
(10.15)\end{array}$ \\
\hline Log likelihood & -46880 & -32231 & -14635 \\
\hline Observations & 73,662 & 50,606 & 23,056 \\
\hline
\end{tabular}


TABLE 14

JOB SEARCH METHOD OVER THE BUSINESS CYCLE, LFS 1984-2009

\begin{tabular}{|c|c|c|c|c|c|c|}
\hline & \multicolumn{3}{|c|}{ Men } & \multicolumn{3}{|c|}{ Women } \\
\hline & \multicolumn{6}{|c|}{ Increasing unemployment } \\
\hline Base: & Degree or & Lower & No & Degree or & Lower & No \\
\hline Advertising and answering & higher & qualifications & qualifications & higher & qualifications & qualifications \\
\hline ads in newspapers & $\mathrm{N}=3,708^{\#}$ & $\mathrm{~N}=12,843$ & $\mathrm{~N}=5,078$ & $\mathrm{~N}=3,724$ & $\mathrm{~N}=11,173$ & $\mathrm{~N}=35,46$ \\
\hline \multirow[t]{2}{*}{ Job centre, careers office, job club } & -0.135 & -0.283 & -0.334 & -0.113 & -0.178 & -0.192 \\
\hline & $(-8.59)$ & $(-24.12)$ & $(-18.44)$ & $(-10.15)$ & $(-19.80)$ & $(-9.82)$ \\
\hline \multirow[t]{2}{*}{ Direct approach to employers } & -0.006 & 0.003 & 0.016 & -0.007 & -0.011 & 0.010 \\
\hline & $(-0.55)$ & $(0.79)$ & $(2.00)$ & $(-0.79)$ & $(-2.12)$ & $(1.13)$ \\
\hline \multirow[t]{2}{*}{ Ask friends and relatives } & 0.008 & 0.034 & 0.049 & 0.005 & 0.014 & 0.026 \\
\hline & $(0.94)$ & $(6.26)$ & $(5.48)$ & $(0.58)$ & $(3.22)$ & $(2.63)$ \\
\hline \multirow[t]{6}{*}{ Do anything else } & 0.038 & 0.033 & 0.021 & 0.040 & 0.034 & 0.020 \\
\hline & $(3.85)$ & $(8.44)$ & $(4.31)$ & $(3.80)$ & $(9.18)$ & $(3.45)$ \\
\hline & \multicolumn{6}{|c|}{ Decreasing unemployment } \\
\hline & Degree or & Lower & No & Degree or & Lower & No \\
\hline & higher & qualifications & qualifications & higher & qualifications & qualifications \\
\hline & $\mathrm{N}=8,588$ & $\mathrm{~N}=33,494$ & $\mathrm{~N}=18,847$ & $\mathrm{~N}=7,065$ & $\mathrm{~N}=30,595$ & $\mathrm{~N}=12,839$ \\
\hline \multirow[t]{2}{*}{ Job centre, careers office, job club } & -0.162 & -0.296 & -0.324 & -0.103 & -0.179 & -0.165 \\
\hline & $(-14.41)$ & $(-43.93)$ & $(-38.15)$ & $(-10.40)$ & $(-29.42)$ & $(-18.61)$ \\
\hline \multirow[t]{2}{*}{ Direct approach to employers } & -0.018 & 0.012 & 0.028 & -0.017 & 0.001 & 0.019 \\
\hline & $(-2.68)$ & $(4.13)$ & $(7.41)$ & $(-2.34)$ & $(0.46)$ & $(4.58)$ \\
\hline \multirow[t]{2}{*}{ Ask friends and relatives } & -0.006 & 0.010 & 0.032 & -0.001 & 0.002 & 0.010 \\
\hline & $(-1.19)$ & $(3.79)$ & $(8.01)$ & $(-0.23)$ & $(0.82)$ & $(2.32)$ \\
\hline \multirow[t]{2}{*}{ Do anything else } & 0.028 & 0.025 & 0.014 & 0.014 & 0.020 & 0.012 \\
\hline & (3.93) & (11.11) & $(6.67)$ & (1.66) & $(8.63)$ & $(4.52)$ \\
\hline
\end{tabular}

Marginal effects of a probit model; t-stats in parenthesis; standard errors are clustered by year x regions. ${ }^{\#}$ Excludes Northern Ireland. All coefficients refer to the dummy for employed job seekers (vs. unemployed job seekers). Other explanatory variables: age, dummies for married/cohabiting, singles, presence of dependent children in the household, levels of education, region, and year. 

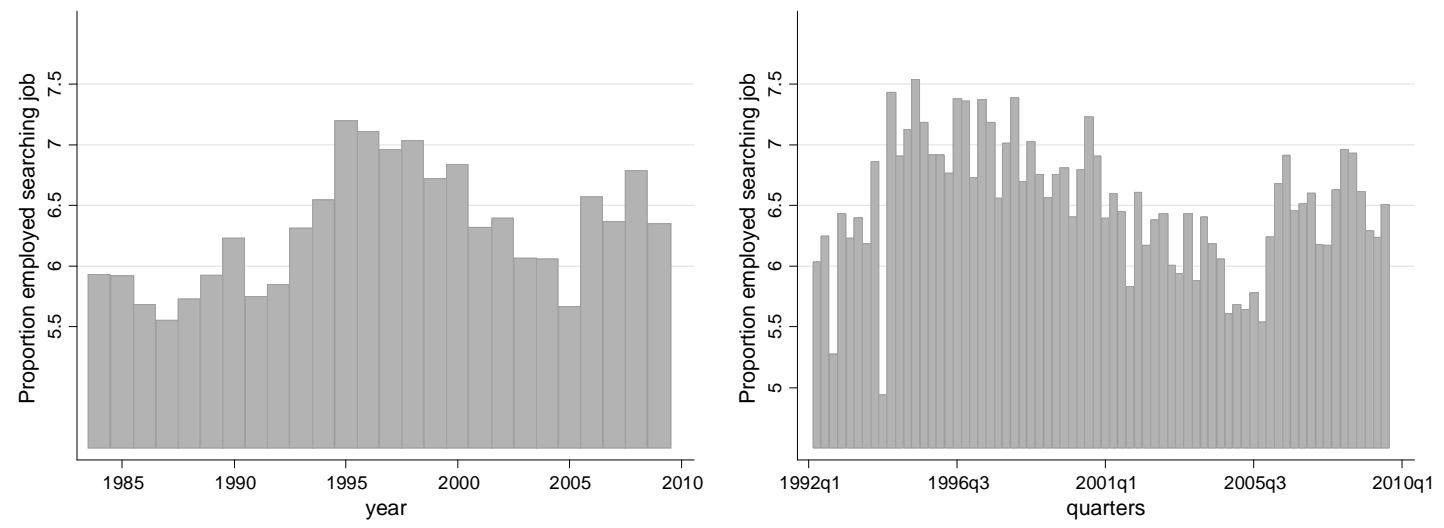

FIGURE1

PROPORTION OF EMPLOYED PEOPLE LOOKING FOR A JOB: LFS 1984-2009; 1992-2009
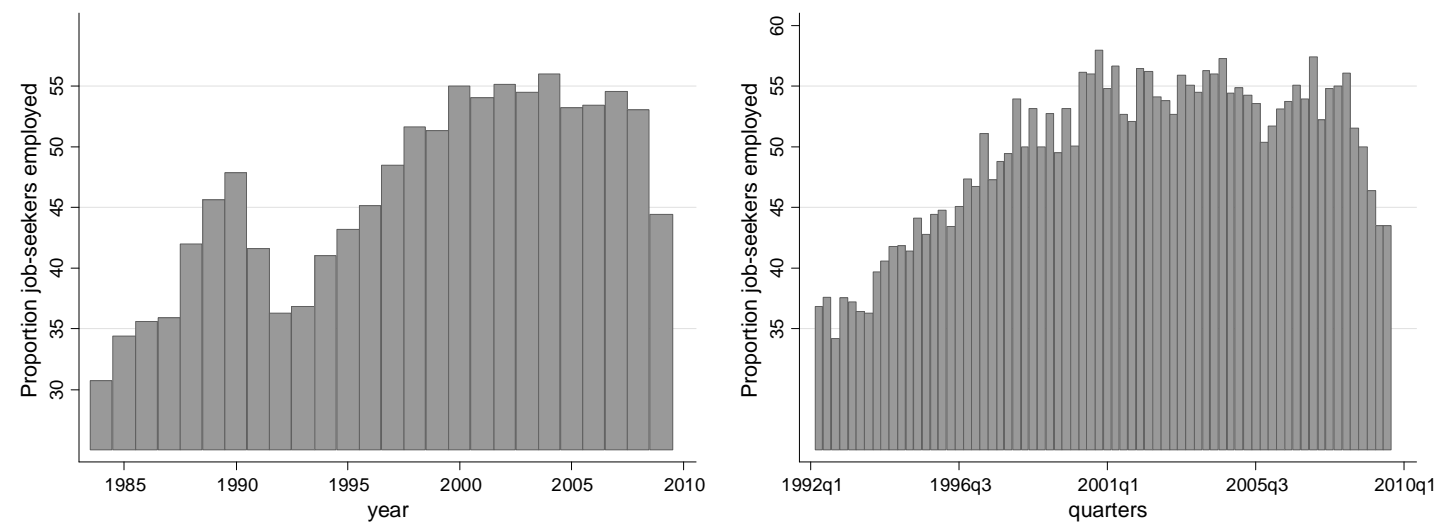

FIGURE 2

PROPORTION OF JOB SEEKERS WHO ARE EMPLOYED: LFS 1984-2009; 1992-2009 


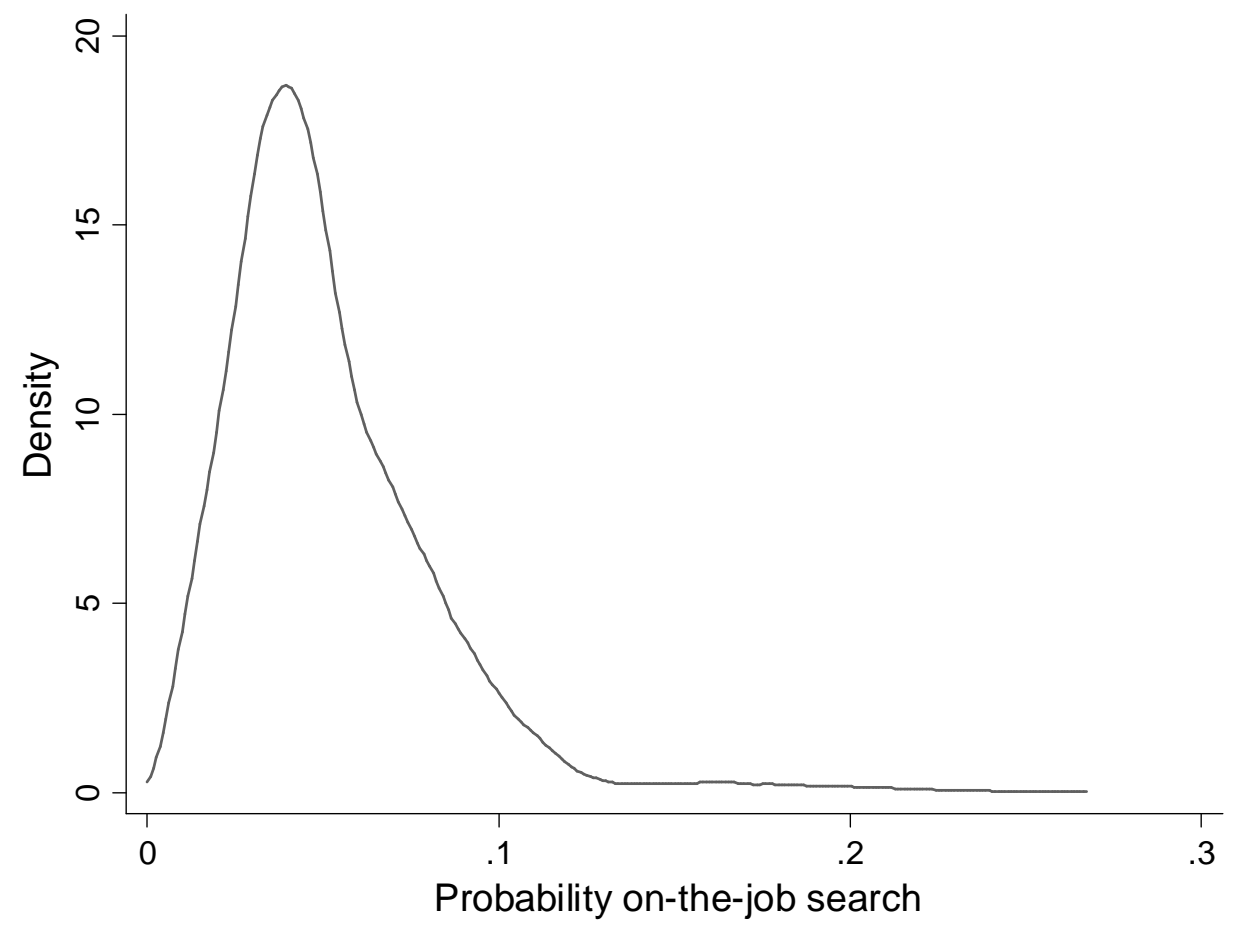

FIGURE 3

DISTRIBUTION OF THE PROBABILITY OF ENGAGING IN ON-THE-JOB SEARCH: BHPS 1993-2007 